\title{
Gastropods of the Lower Jurassic Hierlatz Limestone Formation, part 3. New pleurotomarioideans from the fauna of Hierlatz Alpe (Hallstatt, Austria)
}

János SzaBó

Department of Palaeontology and Geology, Hungarian Natural History Museum, H-1083 Budapest, Ludovika tér 2, Hungary.E-mail: szabo.janos@nhmus.hu

\begin{abstract}
This paper adds sixteen pleurotomarioidean species to the fauna from the type locality area of the Lower Jurassic Hierlatz Limestone Formation (Hallstatt, Austria). Majority of these species are unknown from former publications; only one species has already been recognised from the Bakony Mts (Hungary). Most of the species belong or are related to the genus Pleurotomaria or Laevitomaria but two new genera are also established besides eleven new species: Neorotomaria n. gen., Granulizona n. gen., Pleurotomaria nodulocostulata n. sp., Pleurotomaria wiesberghausensis n. sp., Pleurotomaria nodulocincta n. sp., Pleurotomaria seminodosa n. sp., Pleurotomaria indistincta n. sp., Pleurotomaria nongradata n. sp., Pleurotomaria? homoruspira n. sp., Pleurotomaria? laponya n. sp., Neorotomaria obertraunensis n. sp., Neorotomaria subgradata n. sp. and Granulizona mandli n. sp. With 145 figures.
\end{abstract}

Key words - Granulizona, Hierlatz Limestone, Jurassic, Laevitomaria, Neorotomaria, Pleurotomaria

\section{INTRODUCTION}

This paper is dedicated to those taxa from the unpublished parts of museum collections, which represent the "modern" slit-bearing gastropods in the Early Jurassic faunas of the Hierlatz Alpe. Most of the recognised species are identified as Pleurotomaria Defrance, 1826 (Pleurotomariidae) but several species have so extreme morphology that their assignments to this genus remain uncertain until better material is available; some others need new genera to accommodate them.

\section{LOCALITY, MATERIAL AND METHODS}

Most of the gastropods, studied in this paper, belong also to unpublished parts of those historical collections on which the earliest papers (HörNEs in HAuer 1853; STOLiCzKa 1861) about the fossil content of the Hierlatz Limestone Formation have been based. Some specimens are from subsequent, mostly 
anonymous collectors. The characterization of the material and the locality, provided in the previous parts of the series on the Hierlatz Limestone gastropods (SzABó 2009, 2017), concern also the objects of this paper.

The interpretation of Pleurotomaria in this paper follows the suggestions by MONARI \& GATTO (2013). The measurements below concern the remnants of the shells without reconstruction; the standard measurements are usually not accessible. All specimens are housed in the Museum of the Geologische Bundesanstalt (GBA), Vienna, Austria.

\section{SYSTEMATIC PALAEONTOLOGY}

Class Gastropoda Cuvier, 1795

Order Vetigastropoda Salvini-Plawen, 1980

Superfamily Pleurotomarioidea Swainson, 1840

Family Pleurotomariidae Swainson, 1840

Genus Pleurotomaria Defrance, 1826

Type species - Trochus anglicus Sowerby J., 1818

Pleurotomaria nodulocostulata n. sp.

(Figs 1-13)

Type specimens - Holotype: GBA 2018/002/0001/01; paratypes: GBA 2018/ 002/0001/02-03.

Type locality - Hierlatz Alpe (Hallstatt, Austria).

Type strata - Lower Jurassic Hierlatz Limestone from the interval of Semicostatum Zone (Lower Sinemurian) to Jamesoni Zone (Lower Pliensbachian).

Derivation of name - nodulus $($ Latin $)=$ small node, costula $($ Latin $)=$ small rib; name refers to the ornament of the ramp where no true nodes, characteristic of the genus, can be found.

Diagnosis - Shell of few (6-7) gradate whorls with blunt apex. Angulation and ramp present from second whorl. Angulation sharp on early teleoconch but rounded on penultimate and last whorls. Ramp slightly sloping abapically. Outer face flat or somewhat convex, steeply sloping abapically. Rather wide selenizone at midwhorl. Outer face joined to base along even, wide arch, continued to rim of moderately wide umbilicus. Aperture suborbicular, columellar lip slightly prosocline, strong and smooth. Parietal lip appearing as edge of shell inductura, smoothing coarse ornament of base. Whorls and base spirally ornamented, ramp bearing collabral riblets with granules at crossings with spiral elements. Delicate, dense collabral threads on whole surface of latest whorls and base. 
Material - Three fragmentary specimens (GBA 2018/002/0001/01-03); two of them are in about full grown stage, one is an early teleoconch.

Measurements - Holotype (GBA 2018/002/0001/01): width $17.7 \mathrm{~mm}$, height $18.2 \mathrm{~mm}$, apical angle $83^{\circ}$, pleural angle $77^{\circ}$; paratype (GBA 2018/002/0001/02): height $17.5 \mathrm{~mm}$; paratype (GBA 2018/002/0001/03): height $7.5 \mathrm{~mm}$.

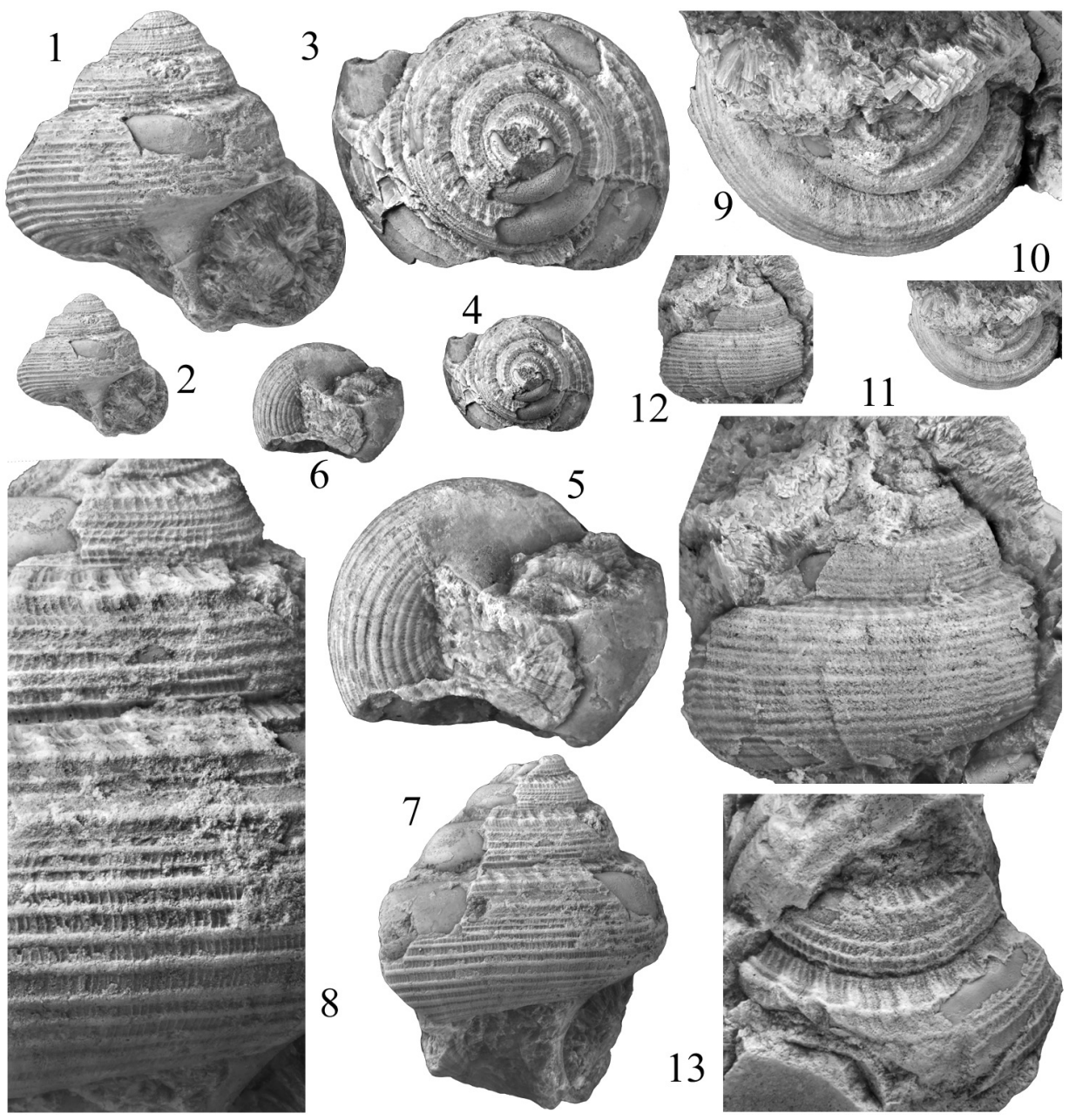

Figs 1-13. Pleurotomaria nodulocostulata n. sp. - 1-8. Holotype (GBA 2018/002/0001/01). - 1-2. Apertural view $(\times 2.3$ and $\times 1)$. - 3-4. Apical view $(\times 2.3$ and $\times 1)$. - 5-6. Basal view $(\times 2.3$ and $\times 1)$. - 7. The best preserved shelly side $(\times 2.3)$. - 8. Details of the ornament $(\times 5.5)$. -9-12. Paratype (GBA 2018/002/0001/02), having a thin coating of granulose calcite. - 9-10. Apical view $(\times 2.3$ and $\times 1)$. - 11-12. Lateral view $(\times 2.3$ and $\times 1)$. - 13. Paratype (GBA 2018/002/0001/03), an early shell in a slightly oblique view, with the onset of the specific spiral thread, developing on the ramp along the angulation of the whorl surface $(\times 5.5)$ 
Description - This species has a shell of rather few whorls, forming a low spire that is about as high as the last whorl. The protoconch and the initial whorls form a blunt apex. Narrow, obscure ramp has developed already on the second whorl then its limiting angulation is also present from the third whorl. The angulation is sharp initially but becoming rounded from the penultimate whorl. The ramp is narrow relative to the outer face; the former belt just slightly the latter area steeply slopes abaxially and abapically. Both belts are flat initially but becoming feebly convex from the penultimate whorl. Position of the selenizone is nearly at the midwhorl, quite near to the outer rim of the ramp. Width of the selenizone reaches $16-17 \%$ of the distance between the nearest sutures. On the last whorl, the outer face is connected to the base along a wide and even arch that turns into a moderately broad umbilicus finally. The aperture is subovate with a broad angle at the meeting of the parietal and umbilical lip. Partially, the peristome is preserved in the holotype: its umbilical lip is straight in prosocline orientation and the parietal lip is represented by the slightly prosocyrt edge of a smooth callosity that evens the rough basal ornament.

The teleoconch is predominantly ornamented by spiral threads and cords; marked transverse ornament appears only on the ramp in form of short, collabral riblets, extending from the suture to the angulation. They bear also granules or nodules at the intersections with the spiral threads. The granules are initially restricted to the thread running on the abaxial rim of the ramp, but from the penultimate whorl, a new spiral thread appears also adaxially from the former one and it becomes also granulate. Weak collabral riblets are present also on the outer face of the earliest teleoconch whorls and form subregular networks with the spiral threads without granules. On this shell part, two of the spiral threads limit the selenizone that is ornamented by similarly strong lunulae. Subsequently the two limiting threads do not strengthen during the growth but a submedian thread also develops and it becomes a cord for the latest whorls as the earlier threads farther along the selenizone also do it. On the base between the indistinct periphery and the umbilicus, several variably wide spiral ribbons also developed. Very fine, nearly periodically repeated, dense growth threads/riblets connect the spiral ornamental elements on the latest whorls and the base; they are present also in the interspaces of the stronger riblets of the ramp. The lunulae of the early selenizone fade away during the growth and only fine growth-lines cross the median thread.

Remarks - The most similar species to P. nodulocostulata n. sp. is P. wiesberghausensis $\mathrm{n}$. sp. The latter species has higher shell (more whorls), steeper ramp, the angulation of the whorls does not change into rounded form on the latest whorls and its nodes reach considerable size. On the outer face, fewer spiral threads/ cords develop that become weakly nodular on the latest whorls; the outer face has a concave belt between the angulation and the abapical edge of the seleni- 
zone on the latest teleoconch whorls (for more details see below). Appearance of a spiral thread on the ramp adaxially from the abaxial angulation is also a specific feature of $P$. nodulocostulata.

Distribution - Within Sinemurian to lowermost Pliensbachian (Lower Jurassic) part of the Hierlatz Limestone Formation in Hierlatz Alpe, Hallstatt, Austria.

Pleurotomaria wiesberghausensis $\mathrm{n}$. sp.

(Figs 14-28)

Type specimens - Holotype: GBA 2018/002/0002/01; paratypes: GBA 2018/ 002/0002/02-03.

Type locality - Hierlatz Alpe (Hallstatt, Austria).

Type strata - Lower Jurassic Hierlatz Limestone from the Semicostatum Zone (Lower Sinemurian) to Jamesoni Zone (Lower Pliensbachian) interval.

Derivation of name - Wiesberghaus is a tourist place, not too far SE from the locality.

Diagnosis - Moderately elevated shell of several (7-8) whorls, forming conoid with blunt apex and gradate outline. Angulation sharp from third to latest whorl; ramp narrow. Outer face as whole steeply sloping abaxially; adapical half barely concave, remaining belt slightly convex. Wide selenizone at midwhorl. Outer face joined to base along rounded angulation. Base flattened and broadly phaneromphalous. Ramp bearing collabral riblets with granules at ridge of angulation initially then riblets and granules together swollen into nodes, extending from suture to selenizone. Fine collabral threads regularly repeated densely on whorl surface, similarly weak lunulae on selenizone. Few spiral threads/cords on whorls: one overlapping ridge of angulation, two threads limiting selenizone and one dividing it. One thread running between selenizone and suture; another thread just overlapped by suture. Nodules on these latter threads from penultimate whorl toward peristome.

Material - Two specimens in (near) full-grown stage and three others represent the early teleoconch; all are damaged (GBA 2018/002/0002/01-05).

Measurements - Holotype (GBA 2018/002/0002/01): height $15 \mathrm{~mm}$, width $14.4 \mathrm{~mm}$, apical angle $76^{\circ}$, pleural angle $71^{\circ}$; paratype (GBA 2018/002/0002/02): height $25 \mathrm{~mm}$, width $21 \mathrm{~mm}$, apical angle $80^{\circ}$; paratype (GBA 2018/002/0002/03): height $7.9 \mathrm{~mm}$, width $8 \mathrm{~mm}$.

Description - The shell consists of 7-8 whorls with moderately elevated spire and a blunt apex. The earliest two whorls have rounded whorl surface; the following whorls are with spiral angulation, causing gradate outline of the shell. The angulation is sharp from the third to the latest whorls. The ramp is narrow and fairly 


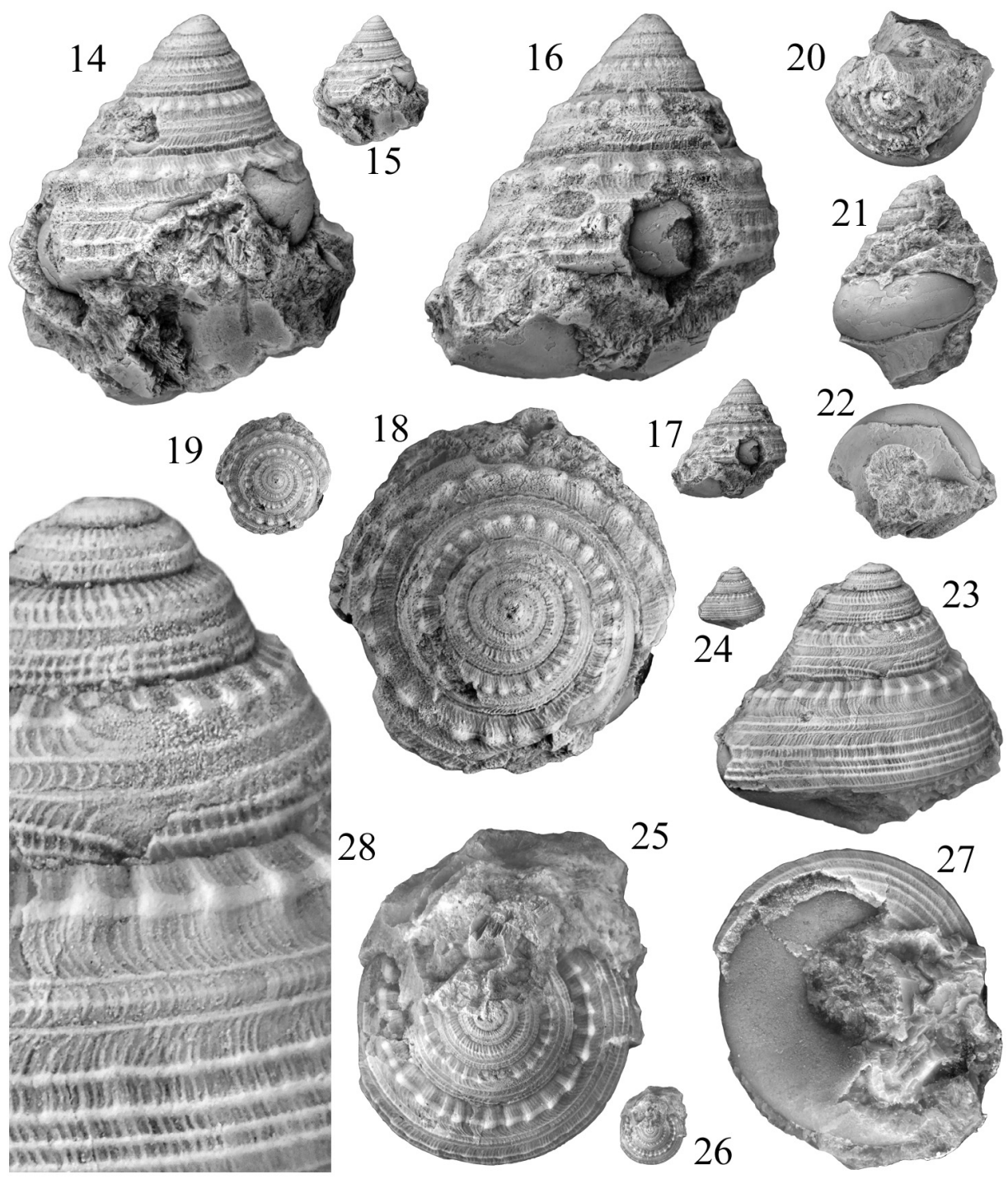

Figs 14-28. Pleurotomaria wiesberghausensis n. sp. - 14-19. Holotype (GBA 2018/002/0002/01). - 14-15. Lateral view better showing the early shell $(\times 3$ and $\times 1)$. - 16-17. Lateral view for the best outline $(\times 3$ and $\times 1)$. - 18-19. Apical view $(\times 3$ and $\times 1)$. - 20-22. Paratype (GBA 2018/002/0002/02), the largest specimen. - 20. Apical view $(\times 1)$. - 21. Lateral view $(\times 1)$. 22 . Basal view ( $\times 1$ ). - 23-28. Paratype (GBA 2018/002/0002/03) to display the early shell morphology. - 23-24. Lateral view $(\times 4.3$ and $\times 1)$. - 25-26. Apical view $(\times 4.3$ and $\times 1) .-27$. Basal view $(\times 4.3) .-28$. Details of the early ornament $(\times 13)$ 
sloping abaxially; it is flat initially but slightly concave from the fifth whorl. The outer face as a whole steeply slopes abaxially; its adapical half is faintly concave, the remaining belt is slightly convex on the latest whorls. A wide selenizone runs at the midwhorl; it is feebly concave in the earliest growth phases but becoming feebly convex on the latest whorls and forms the lower edge of the concave belt of the outer face. The convex belt of the outer face joins to the base through a rounded angulation. The visible shell parts of the holotype and the early shells indicate a base, flattened as a whole with slightly convex wall, and having a rather broad umbilicus.

On the third whorl, the ramp bears dense collabral riblets with granules at the angulation then the riblets and granules together swell into elongate nodes, extending from the suture to the selenizone. They are most prominent at the angulation. On the earliest teleoconch whorls, a narrow network belt of dense collabral and few spiral threads is formed between the selenizone and the suture. From about the fifth whorl, a thinner type of collabral threads substitutes the former one and this ornament type appears also between the selenizone and the upper suture. Similarly weak lunulae ornament also the selenizone. Only few spiral ornamental elements are on the whorls. One thread runs along the ridge of the angulation that becomes a rather wide ribbon for the fifth whorl and lasts through the subsequent shell parts. Two threads limit the earliest selenizone parts, they remain weak also along the next whorls; however, another thread appears within the selenizone in submedian position on about the fourth whorl and it gradually strengthens during the growth. Between the selenizone and the suture, only one spiral thread/cord is visible before the last whorl where a new one, formerly covered by the suture, also appears. These lines bear spirally elongated thickenings from the end of the fifth whorl; the thickenings and their interspaces are arranged to a low undulation of the peripheral shell belt. From the ornament of the base of the holotype, a single thread is visible that seems to be also slightly undulating. On the specimens, representing the early growth stages, sparse spiral threads and dense, delicate growth threads compose the ornament.

Remarks - The early shells are somewhat similar to $P$. nodulocostulata n. sp. and $P$. nodulocincta $\mathrm{n}$. sp. in the early growth stages. The distinction is safe from the fifth whorl by the appearance of the new spiral thread on the ramp in case of $P$. nodulocostulata. In $P$. nodulocincta the nodules are fewer and somewhat larger already from the $4^{\text {th }}$ whorl than in $P$. wiesberghausensis, which possesses almost double number of nodes per whorl. In the latest growth stages further differences appear in the shape and the ornament. The most prominent ones: in $P$. nodulocostulata, no nodes develop in the peripheral region of the last whorls and the angulation of whorls tends to vanish but remains sharp and nodose in $P$. wiesberghausensis. The latest whorls of $P$. nodulocincta change into rounded and the 
ornament becomes coarse with very fine growth lines while the whorls remain angular in $P$. wiesberghausensis with more delicate ornament and keep also the regularly repeating, thin growth-threads.

Since the largest but poorly preserved paratype (Figs 20-22) indicates existence of an additional whorl following the last whorl of the holotype some morphological features may be still unknown.

Distribution - Within Sinemurian to lowermost Pliensbachian (Lower Jurassic) part of the Hierlatz Limestone Formation in Hierlatz Alpe, Hallstatt, Austria.

\section{Pleurotomaria nodulocincta n. sp.}

(Figs 29-46)

Type specimens - Holotype: GBA 2018/002/0003/01; paratypes: GBA 2018/ 002/0003/02-03.

Type locality - Hierlatz Alpe (Hallstatt, Austria).

Type strata - Lower Jurassic Hierlatz Limestone from the Semicostatum Zone (Lower Sinemurian) to Jamesoni Zone (Lower Pliensbachian) interval.

Derivation of name - Nodule $($ Latin $)=$ nodule; cinctus $($ Latin $)=$ belt; referring to the marked, nodulous ribbons of the latest whorl in the peripheral region.

Material - Eight fragmentary specimens (GBA 2018/002/0003/01-08); the holotype probably shows the latest whorls, the others represent the early growth stages.

Measurements - Holotype (GBA 2018/002/0003/01): maximum diameter of inner mould: $14.5 \mathrm{~mm}$; paratype (GBA 2018/002/0003/02): height: $6.5 \mathrm{~mm}$; paratype (GBA 2018/002/0003/03): height: $6.8 \mathrm{~mm}$.

Diagnosis - Rather low spired, slightly cyrtoconidal shell of about six, convex whorls, having narrow subsutural ramp in all growth phases. Ramp appearing from third whorl and abaxially limited by distinct angulation from fourth whorl. Outer face flat initially then becoming convex for last whorl; slightly concave belt just below angulation on all whorls. Suture impressed, selenizone flush with midline cord above middle of outer face. Periphery widely rounded, base as whole somewhat convex and having convex wall and rather narrow umbilicus. Ornament composed of marked, sparse ribbons, nodose on whorl surface in latest growth phases but even on base.

Description - The available material indicates a shell form with rather low spire and somewhat cyrtoconidal outline. A shell of about six whorls with impressed suture can be reconstructed from the specimens in hand. It starts with a blunt apex, a depressed, almost planispiral protoconch of pleurotomariid type. On the third whorl, the initially evenly arched whorl surface changes into angu- 


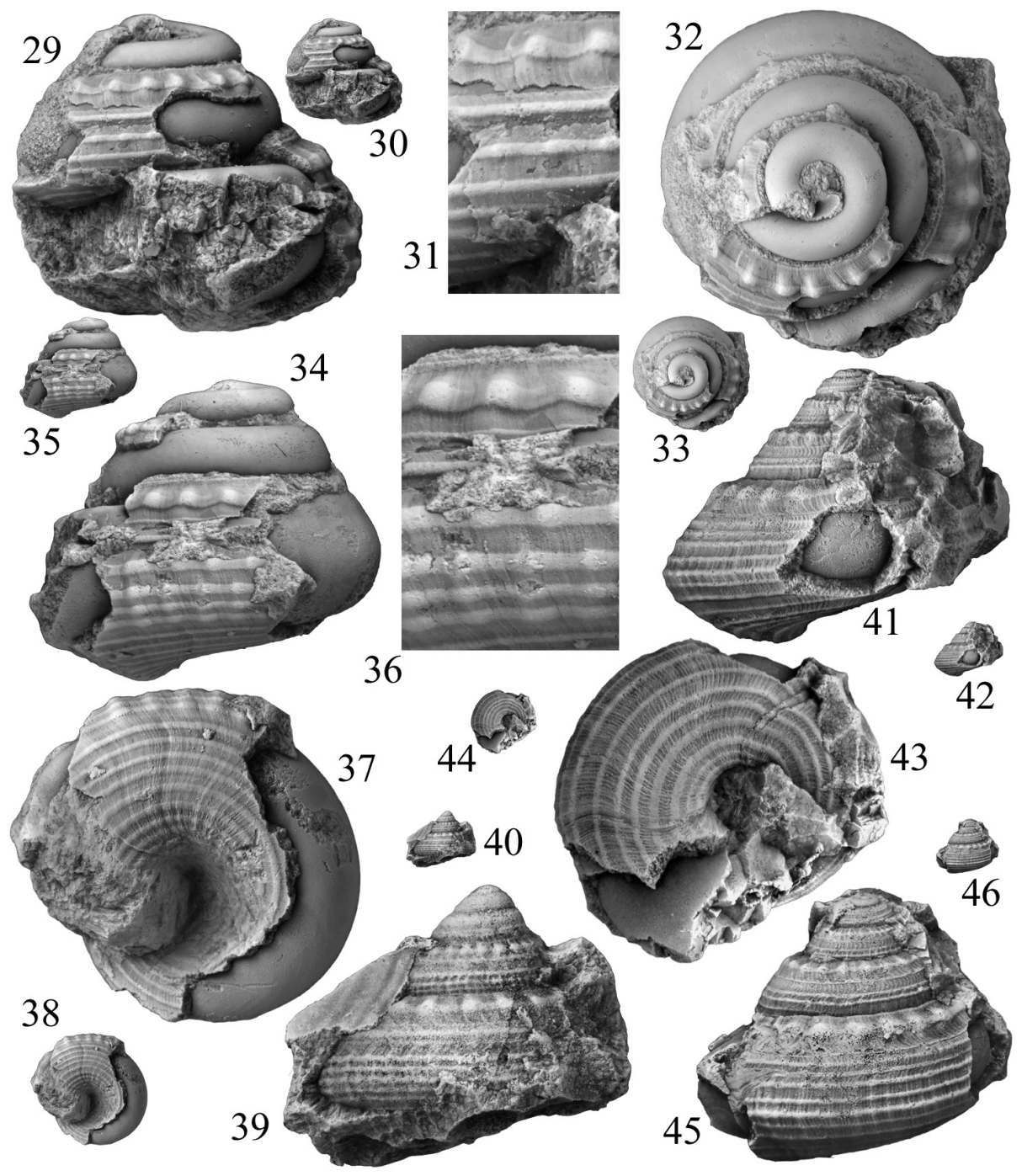

Figs 29-46. Pleurotomaria nodulocincta n. sp. - 29-38. Holotype (GBA 2018/002/0003/01). 29-30. Apertural view $(\times 3$ and $\times 1)$. - 31. Details of the ornament from the penultimate whorl $(\times 6)$. - 32-33. Apical view $(\times 3$ and $\times 1)$. - 34-35. Dorsal view $(\times 3$ and $\times 1) .-36$. Details of the ornament from the last whorl $(\times 6) .-37-38$. Basal view $(\times 3$ and $\times 1)$. - 39-40. Paratype (GBA 2018/002/0003/02), an early shell of the species, having sparser nodules along the ramp than $P$. wiesberghausensis in the same growth stage; nodules below the selenizone of its latest whorl are just appearing, lateral view $(\times 5$ and $\times 1)$. - 41-46. Paratype (GBA 2018/002/0003/03), young specimen, with well-preserved growth threads; the sparse nodes on the ramp indicate its belonging also to $P$. nodulocincta though the abapical belt of the outer face is similar to that of $P$. wiesberghausensis. - 41-42. Lateral view $(\times 5$ and $\times 1)$. -43-44. Basal view $(\times 5$ and $\times 1) .-45-46$. Slightly oblique lateral view $(\times 5$ and $\times 1)$ 
lar; a narrow subsutural ramp develops with sharp abaxial rim. A wide, concave early selenizone is observable above the midline of the outer face from the second whorl. The outer face is flat on the early teleoconch whorls then becomes convex for the last whorl; however, a narrow, slightly concave belt goes along with the angulation on its abapical side in its full length. The selenizone is built just abapically from the concave belt. It changes into convex form from the fifth whorl and has a marked submedian cord from the fourth whorl. The peripheral area is widely arched and turns into the base through a rounded angulation; the periphery itself is well above the rim of the base, it corresponds to the nodulous ribbon abapically just along the selenizone. The base as a whole is convex with a convex wall and a rather narrow umbilicus within a funnel like depression.

The earliest trace of the ornament is observable from the second whorl; it is a network initially on both sides of the selenizone but changes into simply ribbed for the third whorl on the ramp. Between the selenizone and the lower suture, the network ornament persists also on the third whorl. From the fourth whorl, the former collabral elements of the network fully vanish but denser, delicate growth-threads appear instead both on the ramp and the outer face. They also vanish from the penultimate whorl while the spiral threads become strong, wide and nodular ribbons, crossed only by very fine growth lines. The nods of the neighbouring ribbons are not aligned collabrally.

On the ramp, the earliest riblets are dense, regularly repeated, thin and collabral. Small nodules develop on each second riblets on the third whorl then the nodeless riblets soon disappear; only collabrally elongated sparse nodules with their top on the angulation ornament subsequently this region of the shell. These nodes strengthen during the growth. Initially, a spiral thread runs just on the angulation then it also changes into spiral ribbon in the latest growth phases.

The selenizone is formed between two thin spiral threads along full length of the teleoconch; initially thin lunulae ornament it then a new spiral thread appears at about the midline from the fourth whorl and gradually strengthens into a marked cord for the last whorl.

The growth lines are almost orthocline and feebly prosocyrt adapically from the selenizone, slightly prosocline-prosocyrt below the selenizone and parasigmoidal on the base.

Remarks - Mainly owing to the nodose ornament, $P$. nodulocincta n. sp. somewhat resembles $P$. wiesberghausensis $\mathrm{n}$. sp. Their distinction is discussed amongst the remarks of the latter species above.

Distribution - Within Sinemurian to lowermost Pliensbachian (Lower Jurassic) part of the Hierlatz Limestone Formation in Hierlatz Alpe, Hallstatt, Austria. 
Pleurotomaria seminodosa n. sp.

(Figs 47-60)

Type specimens - Holotype: GBA 2018/002/0004/01; paratypes: GBA 2018/ 002/0004/02-03.

Type locality - Hierlatz Alpe (Hallstatt, Austria).

Type strata - Lower Jurassic Hierlatz Limestone from the Semicostatum Zone (Lower Sinemurian) to Jamesoni Zone (Lower Pliensbachian) interval.

Derivation of name - Semi $($ Latin $)=$ half, nodosa $($ Latin $)=$ having nodes; referring to the single row of nodes on the whorls, instead of the two rows, common in Pleurotomaria.

Diagnosis - Conoidal shell of about seven whorls. Whorls low, latest four with increasingly distinct but narrow ramp, slightly sloping abaxially. Much wider outer face, sloping also abaxially but steeply. Wide, convex selenizone in middle of outer face between two concave belts, abapical one narrower; lowermost swollen belt providing periphery. Base flattened as whole with slightly convex wall, and moderately broad umbilicus with wide, funnel like opening. Early whorls bearing nodules along both sutures, latest whorls nodosed only on ramp. Selenizone flat and having sparse lunulae on early teleoconch whorls but becoming markedly convex without lunulae prior to penultimate whorl. Few spiral threads on whorls, more but thinner ones on base. Growth lines delicate on whorls but thin thread-like on base.

Material - Three fragmentary specimens are available (GBA 2018/002/ 0004/01-03); one (paratype) is represented by remnants of the penultimate and the last whorl from the "background collection"; another one (holotype), which is a more complete shell, and an inner mould with small shell pieces have been found during the revisit of the type locality area in 1999.

Measurements - Holotype (GBA 2018/002/0004/01): diameter $13.2 \mathrm{~mm}$; paratype (GBA 2018/002/0004/02): height of the fragment $10.5 \mathrm{~mm}$; paratype (GBA 2018/002/0004/03): diameter of inner mould $14.8 \mathrm{~mm}$.

Description - The shell has a conoidal, slightly gradate outline and consists of about seven whorls, five of which have remained more or less preserved. These whorls are low; the last one is more than four times wider than high. Four of the preserved whorls have narrow, spirally undulating ramp, which is indistinct initially but becomes marked during the growth. Its abaxial edge is a rather sharp angulation with the outer face that is about three times wider than the ramp. The outer face steeply but the ramp just slightly slope abaxially. At the middle of the outer face, wide selenizone runs between two concave belts; the abapical one is narrower than the other one. The selenizone itself is flat initially but markedly convex subsequently; its width is about $20 \%$ of the suture to suture distance. The 


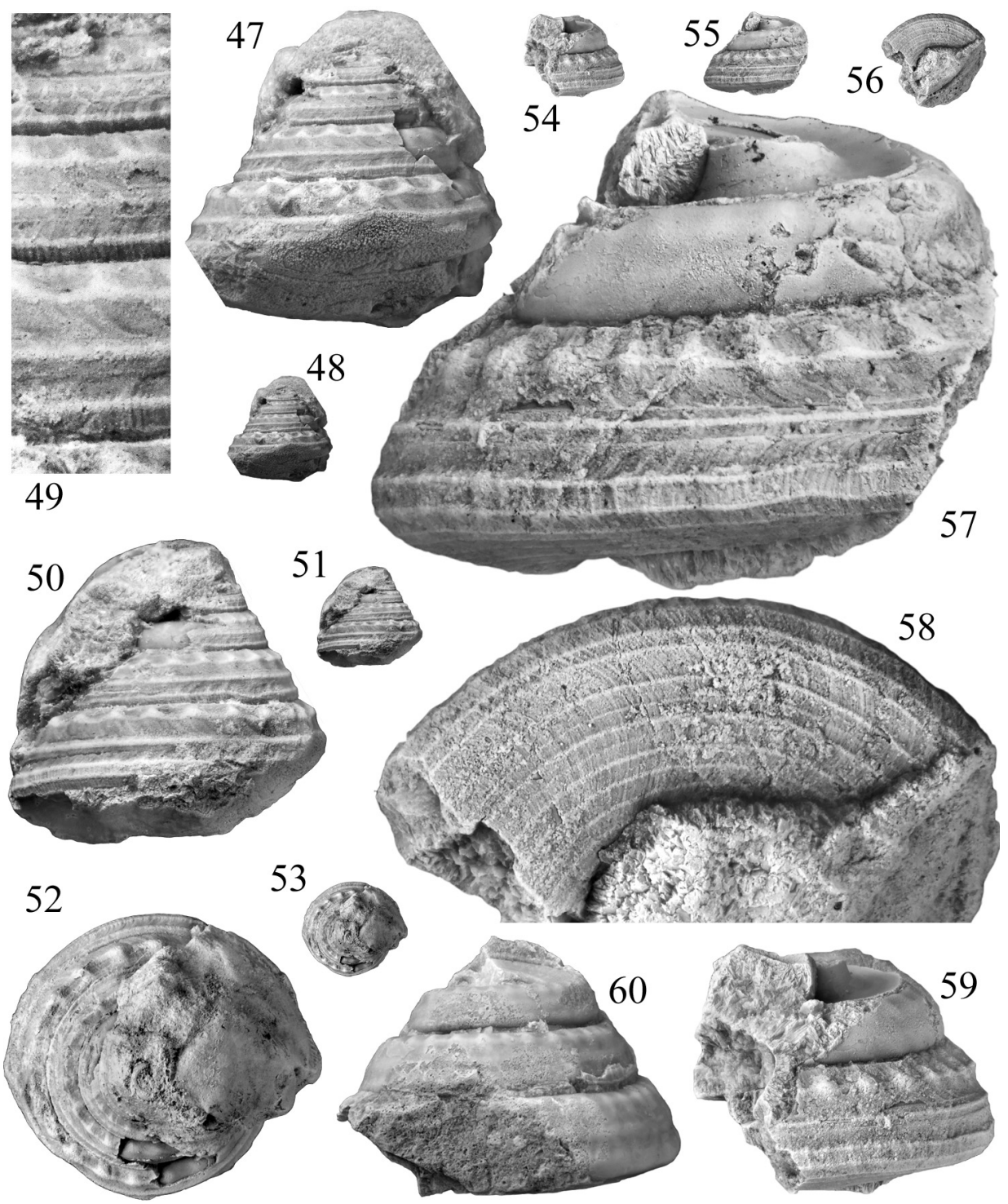

Figs 47-60. Pleurotomaria seminodosa n. sp. - 47-53. Holotype (GBA 2018/002/0004/01). - 4748. Lateral view $(\times 3$ and $\times 1)$. -49 . Development of the ornament in the best preserved section ( $\times 9.5)$. - 50-51. Lateral view $(\times 3$ and $\times 1)$. - 52-53. Apical view $(\times 3$ and $\times 1)$. -54-59. Paratype (GBA 2018/002/0004/02), the ornament of the base is preserved only on this specimen. - 54. Lateral view $(\times 1)$. - 55. Lateral view $(\times 1)$. - 56. Basal view $(\times 1)$. -57 . Lateral view $(\times 6) .-58$. Basal view $(\times 8)$. - 59. Lateral view $(\times 3)$. - 60. Paratype (GBA 2018/002/0004/03), an inner mould with shell particles, the undulation of the periphery does not appear on the outside of the shell $(\times 3)$ 
lowermost belt of the outer face is swollen; this belt provides the periphery of the shell and also on the whorls just above the slightly impressed suture. The base as a whole is flattened and has a slightly convex wall in about the abaxial two thirds of the diameter, and a moderately broad umbilicus with wide, funnel like opening peri-axially.

The poorly preserved early whorls bear periodically repeated nodules along both sutures but the abapical row of nodules vanishes for the latest whorls. The nodes of the ramp gradually strengthen along the full length of the whorls; these nodules extend from the suture to the angulation, there usually suddenly terminate. They are gradually thicker toward the angulation so they cause a characteristic undulation of the ramp and sometimes also the adapical concave zone. The nodules are connected by a spiral thread/cord that is also undulating. Within the concave outer face zones, no ornament appears on the latest whorls. However, short collabral threads are in this belt that are connected to the nodules, which seat on the suprasutural elevation of the early teleoconch whorls that correspond to the subsequently swollen belt. These short threads terminate at the selenizone, which is flat on the early shell with two weak, limiting threads, and bear sparse lunulae. The selenizone gradually changes into convex and the lunulae fade away prior to the penultimate whorl; the limiting threads occasionally also disappear. On the last whorl, two spiral threads are grown also on the periphery; the adapical one is exposed also on the spire whorls but the lower one is just overlapped by the suture there. Differently strong, sparsely spaced spiral threads are on all visible parts of the base that are usually much thinner than the threads of the whorls. The growth lines are delicate on the whorls but thin, thread-like on the base.

Remarks - Pleurotomaria seminodosa n. sp. is well distinguishable from the other species, discussed in this paper on its single row of characteristic nodes, lowest whorls and its very simple and poor accessorial ornament. The ratio of the width to the suture to suture distance is 4.3 in $P$. seminodosa; only $P$. nongradata $n$. sp. approaches this high ratio ( 4) but it has two rows of differently shaped nodes.

Distribution - Within Sinemurian to lowermost Pliensbachian (Lower Jurassic) part of the Hierlatz Limestone Formation in Hierlatz Alpe, Hallstatt, Austria.

Pleurotomaria indistincta n. sp.

(Figs 61-73)

Type specimens - Holotype: GBA 2018/002/0005/01; paratypes: GBA 2018/ 002/0005/02-03.

Type locality - Hierlatz Alpe (Hallstatt, Austria).

Type strata - Lower Jurassic Hierlatz Limestone from the Semicostatum Zone (Lower Sinemurian) to Jamesoni Zone (Lower Pliensbachian) interval. 
Derivation of name - Indistincta (Latin) not clear, obscure.

Diagnosis - Conoidal shell with slightly convex whorls, suture impressed. Ramp narrow and indistinctly developed, outer face feebly convex or flat with shallow concave belt between angulation and selenizone, running at midwhorl. Transition to base rounded; suture running barely below periphery. Base slightly convex with flattish convex wall and moderately broad umbilicus. Umbilical lip obliquely bounding basal and parietal lip, developed as rim of parietal callosity. Early teleoconch bearing network ornament then ramp and peripheral area ornamented with collabral ribs and thin threads, crossed by sparse spiral threads. Ribs of peripheral region abaxially terminating in outermost belt of base, ornamented also with unequally spaced spiral threads, forming network with collabral threads.

Material - Three fragmentary specimens (GBA 2018/002/0005/01-03); one is a shell of a probably full grown animal, the others lack the latest whorls, they represent only the early teleoconch.

Measurements - Holotype (GBA 2018/002/0005/01): height $22.4 \mathrm{~mm}$, early spiral angle $56^{\circ}$; paratype (GBA 2018/002/0005/02): height $10.2 \mathrm{~mm}$, pleural angle $57^{\circ}$; paratype (GBA 2018/002/0005/03): diameter $10.5 \mathrm{~mm}$, pleural angle $60^{\circ}$.

Description - By a reconstruction, the full grown shell has consisted of eight slightly convex or flattened whorls in undamaged state; a moderately impressed suture separates them. From the fourth whorl, a narrow and steep but indistinct ramp is observable. Actually it is so poorly developed also on the subsequent whorls that does not cause clearly gradate shell outline, which is a marked character of a typical Pleurotomaria shell. For the latest whorls of the holotype, only the ornament indicates the place of the ramp. The outer face of the whorls slopes just slightly more steeply than the ramp. Its surface is composed of a shallow concave adapical and a low convex abapical belt. The selenizone is placed to the midwhorl that coincides with the abapical half of the concave zone. The early selenizone is concave but alters into convex from the fourth whorl; its width is about $18 \%$ of the suture to suture distance. Position of the periphery coincides to one of the spiral threads near the suture in the convex band of the outer face. Transition of the outer face to the base is rounded angular; the suture is placed somewhat

Figs 61-73. Pleurotomaria indistincta n. sp. - 61-65. Paratype (GBA 2018/002/0005/02), bearing poorly developed angulation and ramp on the whorl surface. - 61-62. Apertural view $(\times 4$ and $\times 1)$. -63 . Dorsal view $(\times 4) .-64$. Basal view $(\times 4) .-65$. Details of the earliest whorls $(\times 7)$. - 66-68. Paratype (GBA 2018/002/0005/03) with rather clearly visible angulation, outer face and ramp. - 66-67. Lateral view $(\times 4$ and $\times 1)$. - 68. Apertural view $(\times 4)$. - 69-73. Holotype (GBA $2018 / 002 / 0005 / 01)$, the ramp and angulation have vanished from this specimen for the latest whorls, only the row of weak nodules indicates their former position. $-69-71$. Lateral views $(\times 3$, $\times 3$ and $\times 1) .-72-73$. Basal view $(\times 2.7$ and $\times 1)$ 


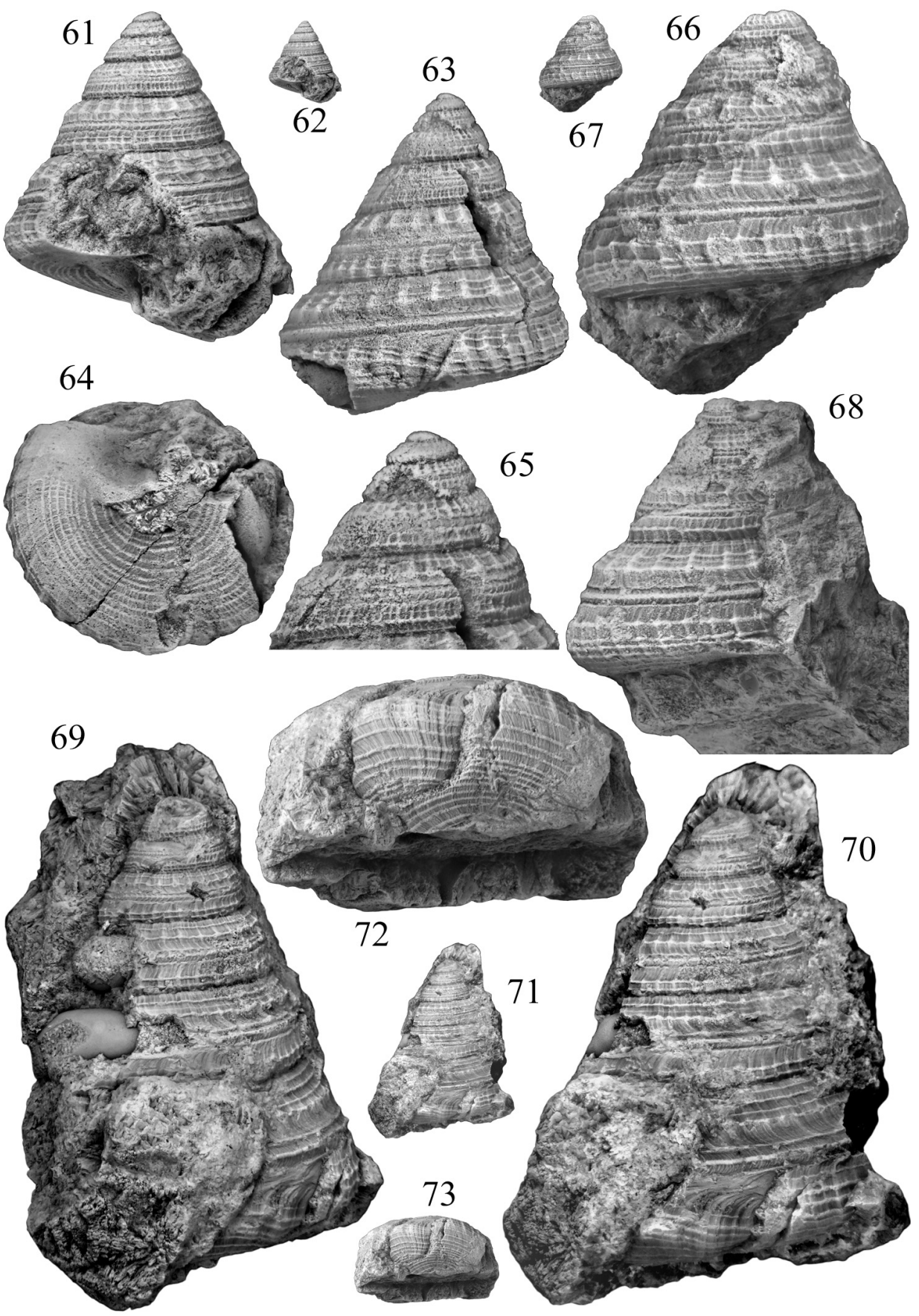


below the periphery of the shells. The base is slightly convex as a whole with flattish convex wall and a moderately broad umbilicus. The umbilical lip obliquely connects the basal and the parietal lip, which has developed as rim of a parietal callosity, smoothing the basal ornament of the former whorl. The outer lip is not preserved in the specimens in hand.

The early ornament of the shell is a network; few spiral threads are crossed by similarly dense and strong collabral threads above and below the selenizone, which is ornamented here by two limiting threads and lunulae, arranged in a density similar to those of the collabral threads. Together with the development of the angulation on the fifth whorl, the sculpture starts to change. On the ramp and in the abapical belt of the outer face, some collabral threads strengthen as ribs, the others in the interspaces of the formers become much thinner; all they are regularly repeated. The ribs and threads of the ramp are orthocline or faintly prosocline and straight. The ribs extend and gradually strengthen from the suture to the limiting angulation where they suddenly terminate. The ribs on the outer face are prosocyrt and feebly prosocline. Crossings of the ribs with the spiral threads result in nodule like undulations. Together with the development of the ramp and the ribs, a submedian thread appears on the selenizone that becomes a marked, smooth cord during the growth; at the same time, the lunulae become thinner, denser and subregularly repeated. The sculpture of the base consists of the terminal parts of the ribs of the lower part of the outer face and a network of threads. The spiral threads are distributed with unequal interspaces, sparser threads occur along the rim of the base and around the umbilicus. Subregularly repeated, thinner collabral threads cross the spiral ones. The growth lines are orthocline on the ramp and prosocline between the ramp edge and the selenizone; these two parts meet almost angularly at the thread on the ridge of the angulation, together they form a prosocyrt-prosocline belt. The growth lines are also prosocyrt-prosocline between the selenizone and the base, and parasigmoidal/ sickle shaped as it is usual in pleurotomariids on the base.

Remarks - The available specimens show considerable variability in the shape and also in the ornament. The ramp is less distinct in the early whorls of the holotype than in the two paratypes, which have not reached the full grown stage. However, the paratypes are also different in this respect since one shows quite clearly gradate shell outline but the other does not. There are differences also in the profile of the outer face; it is flattened with concave belt in the paratypes but feebly convex with concave belt in the corresponding shell parts of the holotype. All specimens differ from each other slightly in the strength, the number and the position of the ornamental elements (see Figs 61-73).

Distribution - Within Sinemurian to lowermost Pliensbachian (Lower Jurassic) part of the Hierlatz Limestone Formation in Hierlatz Alpe, Hallstatt, Austria. 
Pleurotomaria nongradata n. sp.

(Figs 74-84)

Type specimens - Holotype: GBA 2018/002/0006/01; paratype: GBA 2018/ 002/0006/02.

Type locality - Hierlatz Alpe (Hallstatt, Austria).

Type strata - Lower Jurassic Hierlatz Limestone from the Semicostatum Zone (Lower Sinemurian) to Jamesoni Zone (Lower Pliensbachian) interval.

Derivation of name - Non- (Latin) = not, gradatus (Latin) = gradate; referring to the obscure ramp and lack of the gradate shell outline from the latest teleoconch whorls.

Diagnosis - Conoidal shell, composed of very low, concave whorls. Angulation and ramp hardly developed on whorls; shell not gradate. Selenizone wide and flush little below midwhorl. Suture feebly impressed, undulating. Periphery coinciding with swollen, nodose abapical rim of last whorl. Base slightly concave as whole with flattened wall, and moderately broad umbilicus. Few spiral threads and rows of nodes along both sides of suture ornamenting whorls. Selenizone running between two thin spiral threads and having strong, submedian cord and dense, weak lunulae. Rather sparsely spaced spiral threads on base. Growth lines delicate on whole surface.

Material - Two specimens; the holotype is a multi-damaged specimen from a variety of fissure-filling Hierlatz Limestone, predominated by coarse grained crinoid debris and cemented by diagenetic calcite (from field trip in 1999). The apical shell and parts of the latest whorls are lacking; the rest has broken into two parts that are slightly slipped apart. The paratype is in even worse state of preservation. Its shell is at least one whorl longer so shows a slightly different latest whorl.

Measurements - Holotype (GBA 2018/002/0006/01): diameter $15.3 \mathrm{~mm}$; paratype (GBA 2018/002/0006/02): diameter $20.8 \mathrm{~mm}$, preserved height: $18.7 \mathrm{~mm}$.

Description - The available specimens indicate a conoidal shell of numerous $(\sim 10 \pm 2)$ very low whorls; the right number depends on the early shell shape, which may be different from the simple cone of the available latest whorls. The width of the latest teleoconch whorls is $\sim 4$ times larger than their height. They have an indistinct angulation close to the adapical suture and, as consequence, an extremely narrow, rudimentary ramp has developed that is not enough to cause gradate shell outline. The suture is a narrow but rather deep groove that becomes undulating for the latest whorls owing to the marked nodular ornaments of the neighbouring swollen belts. Between the swollen belts, the "outer face" is concave with a flattish deepest part, occupied by the selenizone somewhat below the midwhorl. The selenizone is rather wide, about $20 \%$ of the suture to suture distance 


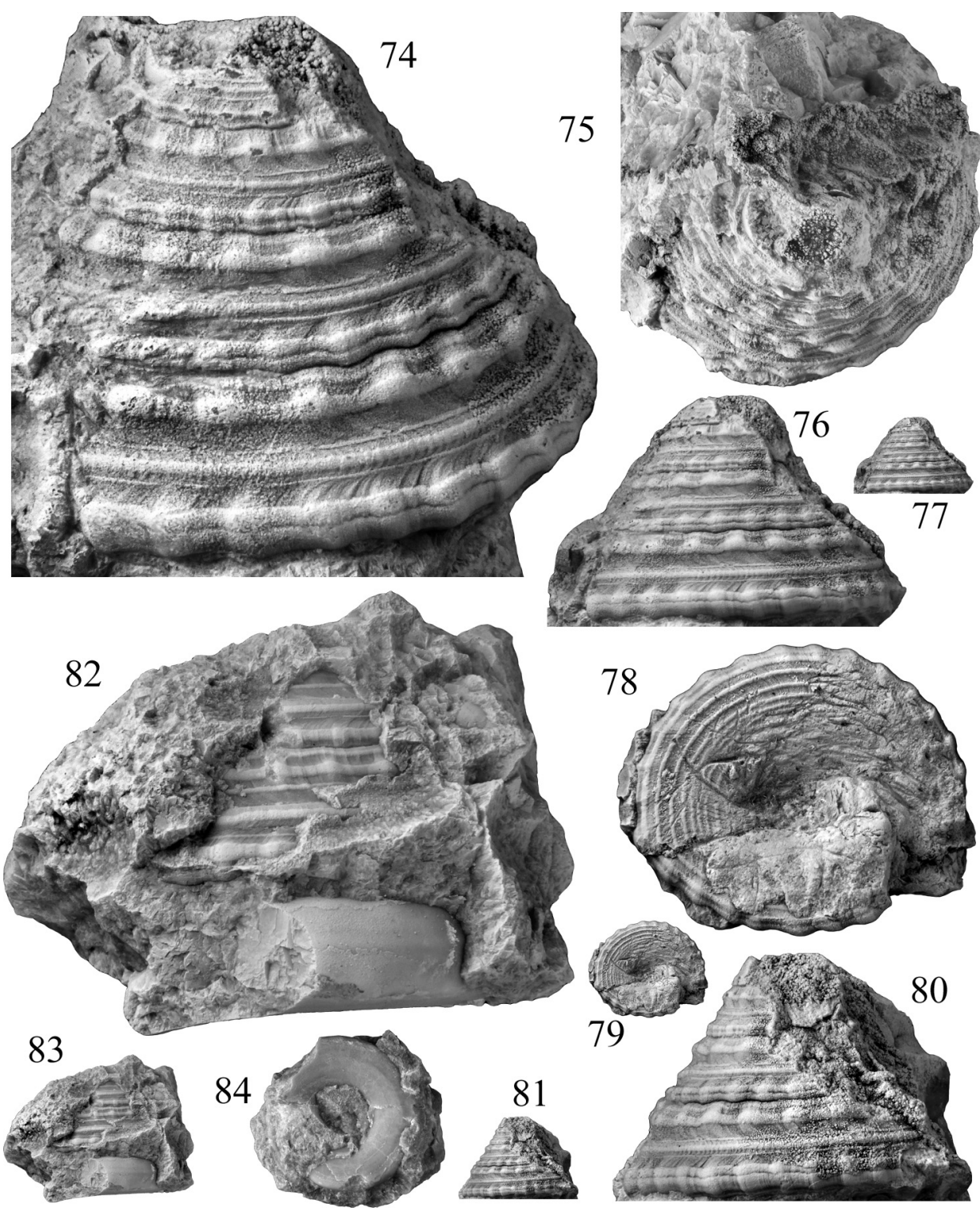

Figs 74-84. Pleurotomaria nongradata n. sp. - 74-81. Holotype (GBA 2018/002/0006/01). - 74. Details of the ornament in a slightly oblique lateral view $(\times 6.5) .-75$. Apical view $(\times 3) .-76-77$. Lateral view $(\times 3$ and $\times 1)$. - 78-79. Basal view $(\times 3$ and $\times 1),-80-81$. "Best outline" view $(\times 3$ and $\times 1$ ). - 82-84. Paratype (GBA 2018/002/0006/02), a larger specimen, which probably represents fully or near fully grown stage (see more in remarks). - 82-83. Lateral view $(\times 3$ and $\times 1)$. $\mathbf{8 4}$. Basal view $(\times 1)$ 
on the latest whorls. The periphery coincides with the abapical swollen belt that turns rounded-angular way to the base, which is slightly concave as a whole with mostly flat wall, and has a moderately wide umbilicus in a funnel like depression.

Two rows of nodules ornament the swollen belts of the whorls, one below, the other above the suture. The adapical row is crossed on the earliest preserved whorls by a single spiral thread, marking the abapical rim of the ramp, then another, weaker one is also added; equally strong, double spiral threads cross the abapical series of nodules on all visible whorls. Two thin threads limit the selenizone that bears also a strong submedian cord, crossed by dense, thin lunulae. Rather sparsely and unequally spaced, thin spiral threads ornament the base. The growth lines are delicate on the entire shell surface; some of them appear as thin, subregularly repeated riblets on the latest whorl between the selenizone and the lower swollen belt.

Remarks - Since a narrow but doubtless ramp is present on the earliest whorls, identification of this species as Pleurotomaria seems correct in spite of some similarity to the type species of Pyrgotrochus P. Fischer, 1885 [P. strobilus (J. A. Eudes-Deslongchamps,1849)] and some closely related species as $P$. precatoria (J. A. Eudes-Deslongchamps,1849) and P. princeps (Koch \& Dunker 1837). However, the extremity of this shell form within Pleurotomaria is obvious.

Distribution - Within Sinemurian to lowermost Pliensbachian (Lower Jurassic) part of the Hierlatz Limestone Formation in Hierlatz Alpe, Hallstatt, Austria.

\section{Pleurotomaria sp. 1}

(Figs 85-90)

Material - Single, fragmentary specimen (GBA 2018/002/0007), consisting of partly preserved last two whorls, and base.

Measurements - Height of the specimen: $12.7 \mathrm{~mm}$.

Description - The remains belong to a species, having rather low shell consisting of about 6 whorls that form a feebly gradate, conoidal outline. The available whorls have a spiral angulation, which abaxially limit a narrow, rather steep, flat ramp above a wide outer face, which slopes just a little more than the ramp. The adapical part of the outer face is concave and actually this belt distinguishes the ramp. At about the middle of the outer face, the convex selenizone can be found. A shallow and narrow concave belt separates it from the slightly swollen, lowermost belt that turns into the concave base through a rounded angulation. The wall of the base is slightly convex but in adaxial-adapically oblique position; most probably, the shell is narrowly phaneromphalous.

The ramp is densely covered by club-like, collabral riblets, their nodes are along the angulation of the whorls. In similar density, the peripheral swollen 
belt is sculptured with prosocline-prosocyrt riblets, which extend also to the outermost belt of the base. In a narrow abaxial belt of the ramp and in the whole swollen zone of the outer face, spiral threads cross the riblets. Two spiral threads are also immediately below the angulation. The selenizone is edged by two spiral threads and a spiral cord runs in its midline, crossed by dense, thin lunulae. Spiral threads ornament also the base. The growth lines are slightly prosocline on the ramp, strongly prosocline and feebly prosocyrt between the angulation and the selenizone, prosocline and just visibly prosocyrt between the selenizone and the outer rim of the base. On the base, the growth lines are opisthocyrt, slightly prosocline in the abaxial two thirds belt.

Remarks - The habit of the ornament, especially on the ramp, is similar to those of the early teleoconch sculpture of $P$. nodulocostulata n. sp., $P$. wiesberghausensis $\mathrm{n}$. sp. and $P$. nodulocincta $\mathrm{n}$. sp. However, in the corresponding size of the shell, no other species has the riblets of the ramp and the peripheral zone in such density and shape as Pleurotomaria sp. 1, profile of the whorls is also different. For the first glance, the remnants are also similar to Pleurotomaria tenuiclathrata by CLARK (1887) but it has wider and concave ramp, consequently clearly gradate outline, convex outer face with selenizone, ornamented by 3-4 spiral threads, and stronger and sparser ribs and nodes.

Distribution - Within Sinemurian to lowermost Pliensbachian (Lower Jurassic) part of the Hierlatz Limestone Formation in Hierlatz Alpe, Hallstatt, Austria.

\section{Pleurotomaria sp. 2}

(Figs 91-96)

Material - Single, poorly preserved specimen (GBA 2018/002/0008) with two, fragmentary, strongly recrystallized whorls, showing enough morphological details to distinguish it from the other species.

Measurements - Height of the specimen: $22.6 \mathrm{~mm}$.

Description - The specimen represents the penultimate and the last whorl of a conoidal shell, having about $40-45^{\circ}$ coiling angle. From the fragments, rather high whorls can be reconstructed. The whorls are of Pleurotomaria type but have only an extremely narrow subsutural ramp, at the same time, the suture is deeply impressed, therefore the gradate outline of the shell has developed indistinctly. The outer face is wide and steep with the selenizone at the midwhorl; a wide concave belt is between the ramp angle and the selenizone but more or less concave interspaces separate also the spiral ornamental elements.

The description of the ornament can be given almost exclusively from the last whorl. Its sculpture is composed of few but robust components; sparse, elongated, collabral elevations are on both sides of the selenizone. On the ramp, these 
rib-like elevations start at the suture and reach their maximum height at the angulation where they cross a rather wide spiral ribbon then vanish in direction of the selenizone within the widest concave belt of the outer face. The selenizone runs between two obscure striae and bears a marked spiral cord in its midline. Below the selenizone, the onsets of the collabral elevations are quite near to the selenizone and they terminate in the outermost belt of the base; a few wide spiral ribbon cross them with node-like peaks. Four of such ribbons are visible on the available specimen but one belongs already to the base.

Remarks - The specimen is somewhat similar to the photos of SACCHI VIALLI (1964), named as Pleurotomaria hettangensis Terquem, 1855 (Plate 1: 7-9). This
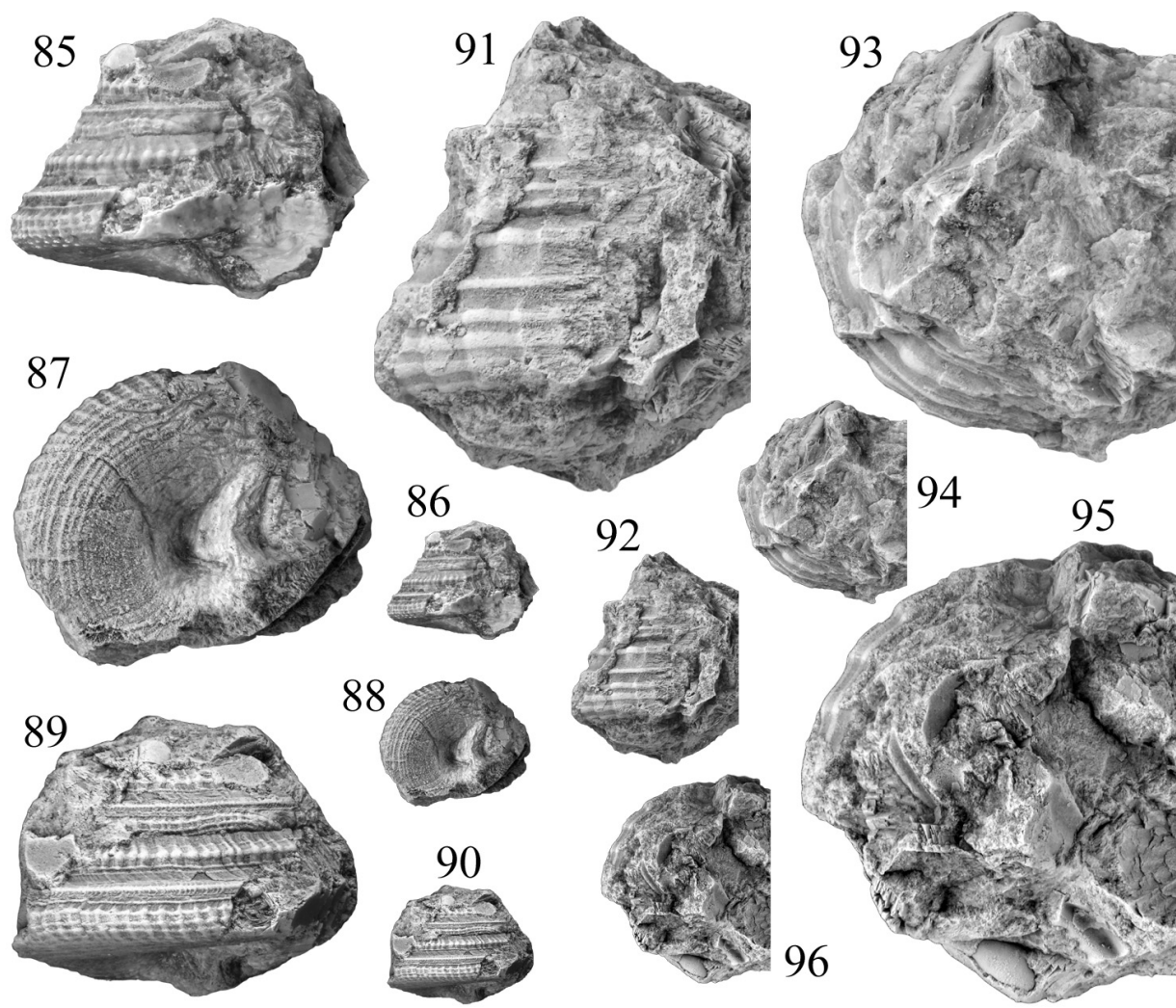

Figs 85-96. Pleurotomaria sp. 1 and Pleurotomaria sp. 2, new species for the Hierlatz Alpe fauna but are either unidentifiable or not suitable to outline new species owing to their poor preservation. - 85-90. Pleurotomaria sp. 1 (GBA 2018/002/0007). - 85-86. Lateral view ( $\times 3$ and $\times 1)$. - 87-88. Basal view $(\times 3$ and $\times 1)$. - 89-90. Lateral view $(\times 3$ and $\times 1)$. - 91-96. Pleurotomaria sp. 2 (GBA 2018/002/0008). - 91-92. Lateral view $(\times 3$ and $\times 1)$. - 93-94. Apical view $(\times 3$ and $\times 1)$. -95-96. Basal view $(\times 3$ and $\times 1)$ 
name is applied instead of Pleurotomaria oblita Parona, 1893 and Pleurotomaria granulatocincta Parona, 1893 that do not belong to $P$. hettangensis by MoNARI et al. (2011, p. 365) opinion. Both species belong to that group of conoidal forms in Pleurotomaria, which have narrow ramp and barely or not gradate outline. Both differ from Pleurotomaria sp. 2 in the more marked nature of the differently arranged spiral ornamental elements that are cords and carinae, not flat ribbons.

Distribution - Within Sinemurian to lowermost Pliensbachian (Lower Jurassic) part of the Hierlatz Limestone Formation in Hierlatz Alpe, Hallstatt, Austria.

Pleurotomaria? homoruspira n. sp.

(Figs 97-109)

Type specimens - Holotype: (GBA 2018/002/0009/01); paratype: (GBA 2018/002/0009/02).

Type locality - Hierlatz Alpe (Hallstatt, Austria).

Type strata - Lower Jurassic Hierlatz Limestone from the Semicostatum Zone (Lower Sinemurian) to Jamesoni Zone (Lower Pliensbachian) interval.

Derivation of name - Homorú $($ Hungarian $)=$ concave spira $($ Latin $)=$ spiral.

Diagnosis - Conoidal early and coeloconoidal latest teleoconch outline. Early teleoconch whorls flat with almost flush suture, latest whorls becoming convex with clearly impressed suture. Selenizone from early near midwhorl position shifting close to edge of base/periphery. Latest whorl with hardly distinguishable ramp and feebly concave outer face. Periphery sharply angular; base low with convex wall and broad umbilicus. Ornament of riblets on both sides of suture and dense spiral threads, crossing them. For last whorl, large, low nod-like swellings developed on ramp and peripheral band. Base with dense spiral threads.

Material - Two strongly worn, badly fragmentary specimens; however, one informs about the early teleoconch whorls, the other shows also characters of the subsequent whorls of a probably full grown specimen. The protoconch and the earliest teleoconch parts are not preserved, the peristomal parts are also lacking.

Measurements - Holotype (GBA 2018/002/0009/01): height $16.5 \mathrm{~mm}$; paratype (GBA 2018/002/0009/02): height: $11.7 \mathrm{~mm}$.

Description - The early spire whorls have conoidal outline but the latest whorls are coeloconoidally added. On the early whorls, the surface is flat or feebly convex with almost flush suture then, from the penultimate whorl, the whorl surface changes into moderately convex with impressed suture. For the last whorl, a rather wide, slightly convex ramp and a feebly concave outer face also develop; an indistinct angulation divides them. Parallel to the ramp, a narrow swollen belt develops adapically along the suture. The moderately wide selenizone runs at about the middle of the early whorls then gradually shifts abapically; on the 


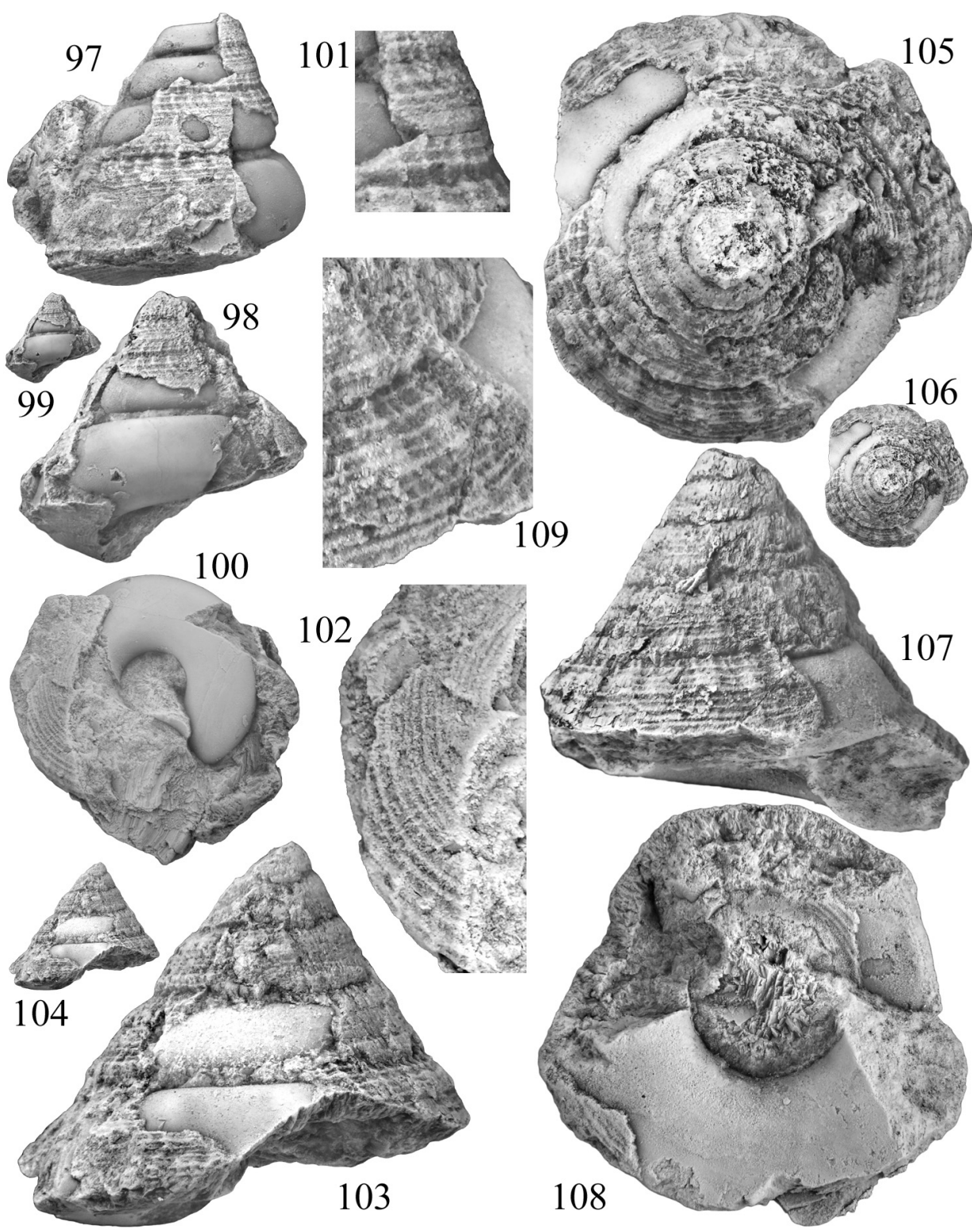

Figs 97-109. Pleurotomaria? homoruspira n. sp. - 97-102. Paratype (GBA 2018/002/0009/02), representing early shell parts of the species. -97 . Lateral view $(\times 3) .-98-99$. Lateral view $(\times 3$ and $\times 1)$. - 100. Basal view $(\times 3) .-101$. The early selenizone $(\times 2.8)$. -102 . Ornament of the base $(\times 7)$. 103-109. Holotype (GBA 2018/002/0009/01), a full grown specimen. - 103-104. Lateral view $(\times 3$ and $\times 1)$. $-105-106$. Apical view $(\times 3$ and $\times 1)$. -107 . Apertural view $(\times 3) .-108$. Basal view $(\times 3)$. - 109. A relatively well preserved part of the selenizone on the last whorl, oblique lateral view $(\times 5)$ 
latest preserved whorl/last whorl, its position is below the midline of the outer face, quite near to the periphery. The periphery is angular in the earlier whorls and sharp on the last whorl. The base is flattened with concave central area and having a convex wall around a broad umbilicus. No peristome part is preserved.

Sparse spiral threads and riblets form a network ornament on the earliest available teleoconch whorls. The riblets are arranged into two rows along the sutures; the adapical ones are prosocline-prosocyrt while the abapical ones incline opisthocline-prosocyrt way. Both rows extend from the suture to the selenizone. The riblets and the spiral threads are nearly of the same strength, excepting the two spiral threads, limiting the selenizone, which are initially much weaker than the others; the selenizone bears weak lunulae and a midline, flattish spiral thread with low, spirally elongated nodules on the early whorls. On the later whorls, the midline becomes even. Nodules appear also at intersections of the riblets and the spiral lines. The riblets and the spiral threads, with increasing strength and increasing number, are present also on all subsequent whorls. During the growth, low nodes, rather undulations, appear then strengthen on the ramp and on the swollen belt along the lower suture. The base is ornamented by spiral threads that are strongest and sparsest near the periphery; their density increases towards the umbilicus whereas the threads become thinner.

Remarks - This species shows a unique combination of some characters which recall different genera. The coeloconoidal outline and the selenizone that shifts near to the abapical edge of the latest whorls refer to Pyrgotrochus; the flat early teleoconch whorl surface with swollen sub- and suprasutural belts also support this genus arrangement. However, development of an angulation and ramp on the penultimate whorl together with the low, subsutural nodes refer to Pleurotomaria. Actually, this morphology indicates a new genus level taxonomic unit but the poor preservation does not permit a satisfactory characterisation; no similar species has been found in the literature.

Distribution - Within Sinemurian to lowermost Pliensbachian (Lower Jurassic) part of the Hierlatz Limestone Formation in Hierlatz Alpe, Hallstatt, Austria.

\section{Pleurotomaria? laponya n. sp.}

(Figs 110-115)

Type specimen - Holotype: GBA 2018/002/0010.

Type locality - Hierlatz Alpe (Hallstatt, Austria).

Type strata - Lower Jurassic Hierlatz Limestone from the Semicostatum Zone (Lower Sinemurian) to Jamesoni Zone (Lower Pliensbachian) interval.

Derivation of name - Laponya (Hungarian) = a synonym for "flat" or "depressed". 
Diagnosis - Depressed shell with spire of subglobular outline. Whorls having obscure angulation between flattish outer face and strongly convex "ramp", sloping both adaxially and abaxially. Suture deeply impressed and running along peripheral angulation of former whorl. Last whorl having high outer face, being rounded angular at rim of base, providing also periphery. Base flattish convex as whole and having convex wall and broad umbilicus. Single spiral thread indicating roughly abaxial edge of ramp and limiting strong, wide and flat collabral ribs, starting at suture. Further spiral threads between ramp and rim of base; two of them limiting selenizone, running at rim of ramp. Exposed abaxial parts of base smooth. Growth lines slightly prosocline and prosocyrt on ramp and prosoclineprosocyrt on outer face, opisthocyrt on abaxial belt of base.

Material - Single specimen without peristomal and earliest shell parts. The base is visible only in small abaxial parts.

Measurements - Maximal visible diameter: $31.5 \mathrm{~mm}$.
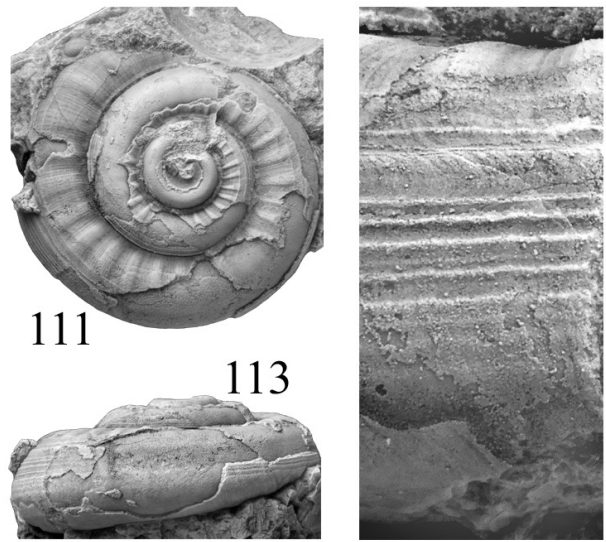

115

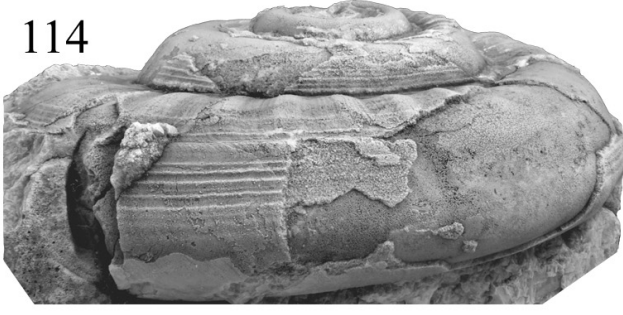

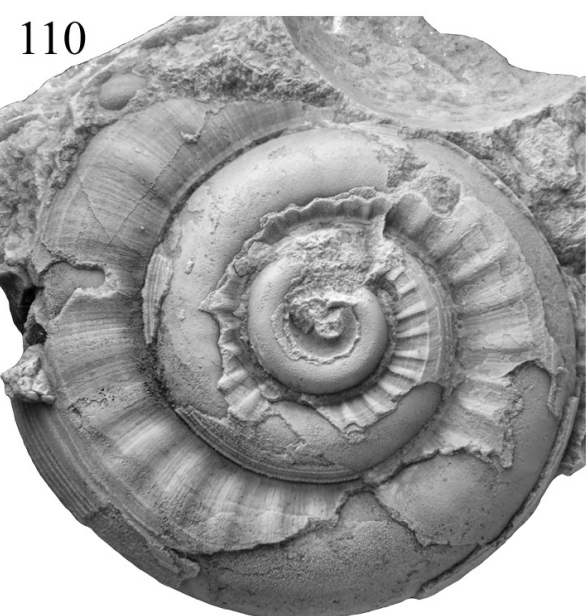

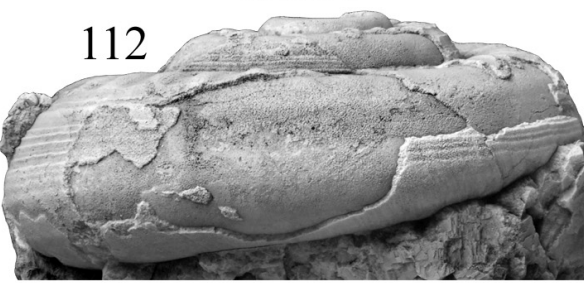

Figs 110-115. Pleurotomaria? laponya n. sp., holotype (GBA 2018/002/0010). - 110-111. Apical view $(\times 2$ and $\times 1)$. - 112-113. Lateral view $(\times 2$ and $\times 1)$. - 114. Oblique lateral view to make the cord along the peripheral angulation of the penultimate whorl visible $(\times 2)$. -115 . Details of the ornament and selenizone $(\times 5$, cut from Fig. 114) 
Description - The shell is depressed with subglobular or perhaps cyrtoconoidal outline of the spire. On the spiral side, the whorls have an obscure, widely rounded angulation between the flattish-convex outer face and the strongly convex "ramp" that slopes both adaxially and abaxially. So, the suture appears deeply impressed; its position is below the angulation of the previous whorl somewhat abaxially from the selenizone. The selenizone itself is placed just below the angulation of the whorls; its adapical edge seems to coincide with the angulation. The width of the selenizone is above $20 \%$ of the whorl height, suture to suture distance, on the penultimate whorl. On the last whorl a rather wide outer face is observable with a clear but rounded angulation at the rim of the base that corresponds also to the periphery. The base as a whole is flattish convex with a convex wall, and a broad umbilicus as it is suggested by the scar of the earliest shell part.

The ramp is sculptured by marked, wide, regularly repeated collabral costae and thin growth threads between the suture and a spiral thread, running near the angulation and the adaxial edge of the selenizone. The costae are sparsely distributed but the growth threads are dense and equally cover the costae and their interspaces, too. The early costae are sharp but they become wider, flat undulations towards the peristome. The costae gradually widen from the suture abaxially then rather suddenly terminate at the aforementioned spiral thread. Between this boundary thread and the edge of the selenizone, a narrow flat-concave belt can be found with another spiral thread and undulations, caused by the ends of the costae. Two spiral threads border the selenizone that is smooth on the whorls, on which it is preserved. Further spiral threads are between the selenizone and the rim of the base. On the peripheral angulation, a spiral cord is observable just above the suture that vanishes for the latest whorl (Fig. 114). The visible abaxial parts of the base are smooth. The growth lines are slightly prosocline and prosocyrt on the ramp and prosocline-prosocyrt on the outer face, opisthocyrt on the abaxial belt of the base.

Remarks - The ribs of the ramp and the track of the selenizone are reflected on the inner mould as undulation. Between the trace of the selenizone and the periphery, the outer face of the inner mould is feebly concave.

Pleurotomaria? laponya n. sp. is similar to the depressed "varieties" of $P$. debuchii J. A. Eudes-Deslongchamps, 1849. Actually the taxonomical status of this "mega-species" has not yet been arranged satisfactorily (see also MONARI \& Gatтo 2013, p. 771). The situation is similar to the case of "Pleurotomaria foveolata" (SzABó 2017): is Pleurotomaria debuchi a single species or a group of unsatisfactorily known species, and does this/these species belong to Pleurotomaria at all? In the Hierlatz Alpe fauna, some "varieties" of $P$. debuchi occur (STOLICZKA 1861, SzABó 2008, 2009) but all are different from P.? laponya n. sp. The most 
similar ones are those forms, which have been identified by STOLICZKa (1861) as P. suessi (see Szaвó 2008); however, though they have similar shape, their ornament is strongly different since they have dense and marked spiral threads on the ramp, and their denser riblets are almost as thin as the spiral threads; they lack the dense growth threads that are present on the ramp of P.? laponya n. sp. The question mark after the genus name indicates the opinion of the writer that application of "Pleurotomaria" may be not right for this and the similar species.

Distribution - Within Sinemurian to lowermost Pliensbachian (Lower Jurassic) part of the Hierlatz Limestone Formation in Hierlatz Alpe, Hallstatt, Austria.

\section{Genus Neorotomaria n. gen.}

Type species - Neorotomaria obertraunensis $\mathrm{n}$. sp.

Derivation of name - A modification from Pleurotomaria; ขร́oร (neos, Greek) = new.

Diagnosis - Conoidal shell consisting of rather high number of low whorls, and flat to concave base with angular contact to the whorl surface. Suture impressed. Whorls convex as whole but having concave spiral belts. Angulation with narrow ramp occurring on latest whorls or never. Selenizone at or below midwhorl. Early teleoconch selenizone bearing midline thread, corrugated by coarse lunulae then changing into smooth carina. Ornament of regularly repeating, sharp riblets and spiral threads with granules at crossings on early teleoconch. Spiral threads, cords and carinae with or without nodules and tubercles ornamenting all later teleoconch whorls and base, crossed by thin, subregularly repeated growth threads and lines.

Description - The earliest shell parts, the protoconch and one or two teleoconch whorls, are unknown in both species, ascribed to Neorotomaria. The first preserved teleoconch whorls are more convex than the succeeding ones, which become flattened and may have even feebly concave belts above and/or below the selenizone. The submedian cord/carina of the selenizone is one of the most prominent morphological elements on the whorl surface. No true spiral angulation develops on the early teleoconch whorls between the sutures but the transition of the whorl surface towards the base is angular just like on the latest whorls. The suture is moderately impressed. The base is flat or concave as a whole with feebly convex or flat wall, and has a rather broad umbilicus. No peristome part is known. Width of the selenizone is quite high, $15-18 \%$ of the distance between two neighbouring sutures; their position is at or just little below the midwhorl. The periphery of the whorls usually coincides with the abaxial rim of the base; sometimes the cord/ carina of the selenizone seems to be the farthest line from the axis. 
The earliest known whorls have a network ornament. From the network, the transverse elements, which are collabral riblets, gradually vanish or weaken but the spiral components are present also along the next shell parts, and a few new ones also appear. Beside them, granules or granule-like, marked lunulae ornament the submedian thread of the early selenizone that becomes a smooth cord, then carina on the succeeding whorls. Granules appear also in the intersections of the network ornament and along some other spiral threads. In the subsutural belt, nodules develop from the granules at crossings with a stronger spiral cord, usually they are collabrally elongated and fading out toward the selenizone. This row of nodules corresponds to the adapical series of nodes in Pleurotomaria; they will strengthen as low angulation of the latest whorls in Neorotomaria subgradata n. sp. In later growth stages new types of riblets, granules and nodules also appear mainly above the rim of the base. The growth lines may appear occasionally also as fine riblets. Sparse spiral cords and threads or ribbons ornament the base. The growth lines are of pleurotomariid type on the whorls, i.e. they approach the rims of the selenizone asymptotically and meet it under low angle. Their shape is strongly prosocyrt and prosocline above and strongly prosocyrt but opisthocline below the selenizone, respectively. Together, they indicate a just slightly prosocline outer lip and a moderately deep sinus. The growth lines of the base are feebly prosocline and opisthocyrt.

Remarks - In both Neorotomaria species, the earliest preserved parts are about the 3rd or 4th teleoconch whorls, yet having no angulation. In this growth stage, Pleurotomaria Defrance, 1826 species already have clearly angular whorl surface (MONARI \& GatTo 2013, p. 754; see also Figs 23, 25, 28, 45 here). In Neorotomaria, angulation does not develop at all in $N$. obertraunensis $\mathrm{n}$. sp. but it is lacking only from the earliest whorls in N. subgradata n. sp., then an obscure angulation gradually develops. Since the monotype of the type species is not a full grown specimen, there is a possibility that angulation develops similarly to $N$. subgradata but only in the latest growth phase. Therefore, the long early lack of angulation means the major difference from Pleurotomaria.

In the coarse nature of the early lunulae, the early teleoconch whorls of Neorotomaria n. gen. shows some similarity to Granulizona n. gen. (see below), however, the details of the ornaments are different. Riblets in Granulizona are sparse, wide, actually transverse undulations, crossed by dense, thin spiral threads that form a pattern, different from the sparse network of sharp riblets and similarly strong spiral threads in Neorotomaria. The subsequent whorls become more convex with rather deeply impressed suture in both genera, however, Granulizona has exclusively spiral ornament on this shell part.

Distribution - Sinemurian to Pliensbachian (Lower Jurassic) of the Hierlatz Alpe (Hallstatt, Austria). 
Neorotomaria obertraunensis n. sp.

(Figs 116-119, 130)

pars 1861 Pleurotomaria princeps Koch et Dunker - STOLICZKA, p. 189, pl. 4, figs 7 a-c.

pars 2009 Pyrgotrochus? cf. precatoria (J. A. Eudes-Deslongchamps, 1849) - SzABó, p. 47, Figure

39: D-E.

Type specimen - Holotype: GBA 2008/69/43/2/2.

Type locality - Hierlatz Alpe (Hallstatt, Austria).

Type strata - Hierlatz Limestone within the Lower Sinemurian to lowermost Pliensbachian (Lower Jurassic) interval.

Derivation of name - Obertraun is a nearby village NE from the type locality.

Diagnosis - Conoidal shell consisting of convex early teleoconch whorls, separated by impressed suture; latest whorl(s) not preserved. Base feebly concave as whole with flat wall and broad umbilicus; abaxial rim of base angular. Selenizone position little below midwhorl. Early whorls with dense, sharp, collabral riblets crossed by few, marked spiral threads; granules subsuturally at crossings, strengthening subsequently as collabrally elongated elevations, weakening towards selenizone and making shell wavy. Early riblets gradually vanishing but new ones appearing along abapical suture together with new granules. Selenizone having midline thread with sparse and coarse lunulae on early teleoconch whorls then changing into smooth cord/carina.

Material - Single multi-damaged specimen without protoconch and latest whorls. On base of the latest whorl, trace of lost further whorl(s) is recognisable.

Measurements - Height of remnant: $20 \mathrm{~mm}$, maximal diameter of shelly parts: $18 \mathrm{~mm}$.

Description - Outline of the shell is conoidal, the remnants of the earliest and latest shell parts suggest trochiform undamaged shape. The whorls are convex without angulation, and rather low; they are about three times wider than their height (= distance of nearest sutures). A slightly impressed suture separates them while follows the outermost spiral cord of the base, running next to the angular periphery of the whorls. The position of the selenizone is little below the midwhorl; its submedian elevation provides the highest spiral line of the shell surface. The base is feebly concave with flat wall and a broadly open umbilicus, having a rounded angular basal rim. No part of the peristome is preserved but the remnants of a damaged whorl on the apparent base of the available specimen indicate a parietal lip, appearing as thin shell enamel that does not hide fully the coarse elements of the basal ornament (spiral cords).

The early teleoconch whorls are ornamented by dense, sharp, collabral riblets above and below the selenizone that are crossed by single marked spiral threads in the middle of both belts, resulting in a kind of network. Another strong spiral thread is just above the suture. Granules developed in the subsutural 
belt at the crossings. Subsequently these granules become sparser and strengthen as collabrally elongated, nod-like elevations, which are strongest at the suture and vanish before reaching the selenizone. The elevations are internally empty so making not only the shell but also the inner mould wavy. The early riblets gradually weaken then disappear but new, dense ones appear along the abapical suture together with rows of new granules. A few new spiral lines also appear during the growth, the earliest one below the adapical suture, subsequently one above the selenizone and one between the two strong treads above the suture. The earliest visible part of the median elevation on the selenizone is a thread with dense, granule-like lunulae that gradually become subaxially more elongated and thinner while the thread strengthens as cord. On the latest available whorl, the lunulae are fully absent and the elevation is a cord with smooth surface. The base is ornamented by $7-8$ sparse, differently strong spiral ribbons that are crossed by dense, very thin collabral threads.

Remarks - In the available Neorotomaria obertraunensis specimen, angulation and ramp on the whorl surface do not appear at all. However, this statement is true only for the earliest whorls in N. subgradata n. sp, then an obscure angulation and ramp gradually develop for the latest whorls. Since the shape and ornament of the latest whorls of $N$. obertraunensis show clear divergences from the whorls of the same growth stages of N. subgradata, the unknown latest whorls of $N$. obertraunensis must be also different from the corresponding parts of the other species (see also Figs 129-130). Though the early teleoconch whorls have similar pattern of the ornament in both species, on the measurements and arrangement of its elements they are also distinguishable.

Distribution - Within Sinemurian to lowermost Pliensbachian (Lower Jurassic) part of the Hierlatz Limestone Formation in Hierlatz Alpe, Hallstatt, Austria.

Neorotomaria subgradata n. sp.

(Figs 120-129)

Type specimens - Holotype: GBA 2018/002/0014/01; paratype: GBA 2018/ 002/0014/02.

Type locality - Hierlatz Alpe (Hallstatt, Austria).

Type strata - Lower Jurassic Hierlatz Limestone from the interval of Semicostatum Zone (Lower Sinemurian) to Jamesoni Zone (Lower Pliensbachian) interval.

Derivation of name - Referring to the obscurely gradate latest whorls.

Diagnosis - Widely conoidal shell with arched convex early teleoconch and obscurely gradate latest whorls; suture slightly impressed. Convex, wide seleni- 
zone bearing midline cord, placed somewhat below midwhorl. Narrow, very steep and feebly concave ramp developing for last three whorls. Outer face wide, just little steeper than ramp; two concave belts along selenizone. Periphery running at edge of base, being rounded angular. Base and its wall flattened, widely phaneromphalous. Network ornament on early whorls with sparse and coarse lunulae on midline cord of selenizone. Subsutural riblets becoming nodules in early growth phase, suprasutural nodules develop from penultimate whorl.

Material - Two specimens; a less incomplete one (GBA 2018/002/0014/01) that has remains of the early teleoconch and also the latest whorls (holotype); the other one (GBA 2018/002/0014/02) represents only early shell parts. Further specimens may be in the GBA 2008/69/43/2/1 inventory unit.

Measurements - Holotype (GBA 2018/002/0014/01) height of remnants: $22.7 \mathrm{~mm}$, maximum diameter of shelly parts $25.5 \mathrm{~mm}$; paratype (GBA 2018/ 002/0014/02) width: $9.4 \mathrm{~mm}$.

Description - The specimen in hand is a fragmentary, wide conoidal shell that has originally consisted of about $10 \pm 1-2$ whorls, which are slightly convex in the early and obscurely gradate in the succeeding growth stages. The latter have narrow, gently sloping, feebly concave ramp and a much steeper outer face, composed of two concave belts that are separated by the convex selenizone. The selenizone is placed below the midwhorl in a position that roughly coincides with the midline of the outer face on the gradate whorls. The shell remnants are indicative of a low, flat or feebly concave and broadly phaneromphalous base, meeting the last whorl surface through a rounded angulation that corresponds also to the periphery of the shell.

The first preserved whorl, which is about the fourth one from the protoconch, has only a small fragment of shell, indicating network ornament just above the suture from equally strong spiral and collabral threads. This network is present also on the next whorl between the suture and the selenizone, where three spiral threads give the frame, one just above the suture, another abapically limits the selenizone and one between the formers; regularly repeated, equally strong, short threads/riblets cross them. A spiral thread edges the selenizone also on the adapical side. There is also a spiral thread in the midline of the selenizone that is stronger than the limiting ones; marked lunulae cross it. A distinct spiral thread is about halfway between the selenizone and the adapical suture, and a thin line above the former one. Short, dense riblets of two, alternating thickness start from the suture and strengthen toward the marked spiral thread, where the stronger riblets form nodules at the intersections then all riblets weaken but all reach the edge of the selenizone. On the next whorls, the strong spiral thread adapically from the selenizone and the two threads at and above the lower suture become gradually stronger. Nodules appear also on the latter two threads; all 


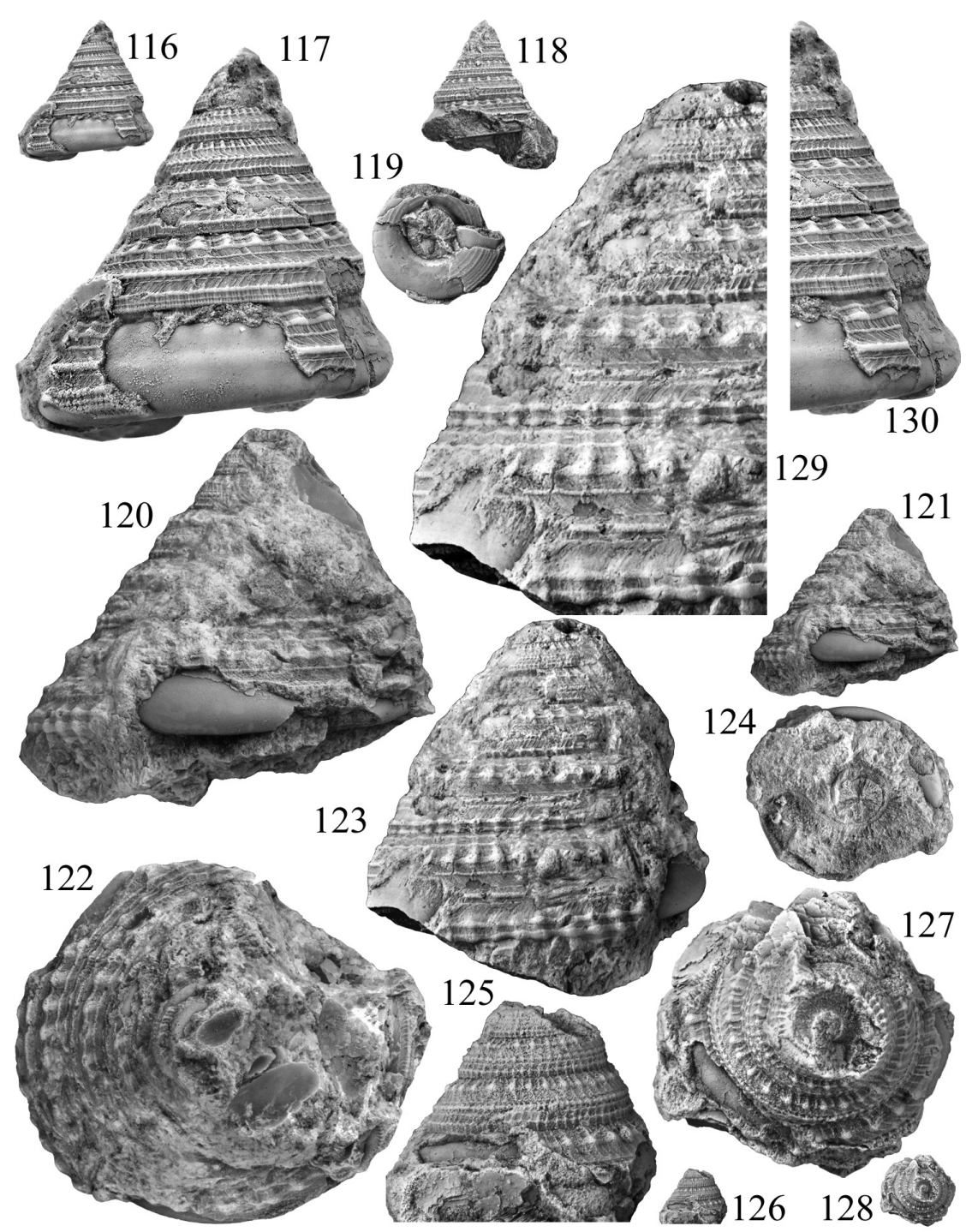

Figs 116-130. Neorotomaria obertraunensis n. sp. and Neorotomaria subgradata n. sp. - 116-119. Neorotomaria obertraunensis $n$. sp., holotype (GBA 2008/69/43/2/2). - 116-117. Lateral view ( $\times 1$ and $\times 3)$. - 118. Apertural view $(\times 1)$. - 119. Basal view $(\times 1)$. - 120-128. Neorotomaria subgradata n. sp. - 120-124. Holotype (GBA 2018/002/0014/01). - 120-121. Lateral view to show the outline of the shell $(\times 2$ and $\times 1)$. -122 . Apical view $(\times 2)$. -123 . Lateral view with the largest surface of preserved ornament $(\times 2)$. -124 . Basal view to document the presence of a broad umbilicus $(\times 1)$. - 125-128. Paratype (GBA 2018/002/0014/02) representing early shell parts of the species. 125-126. Lateral view $(\times 4$ and $\times 1)$. - 127-128. Apical view $(\times 4$ and $\times 1)$. 129-130. Comparative images of two Neorotomaria species to follow the similarities and divergences in the development of the shells. - 129. Neorotomaria subgradata n. sp. $(\times 3) .-130$. Neorotomaria obertraunensis $(\times 3)$ 
nodose riblets become gradually marked ribs and nodes. The adapical and abapical rows of nodes are not aligned but those along the lower suture and in the outermost belt of the base are arranged along low, collabral elevations/ribs. For the last whorl, the spiral threads in the neighbourhood of the periphery become ribbons that widen at all nodes.

Remarks - See distinction from N. obertraunensis above.

Distribution - Within Sinemurian to lowermost Pliensbachian (Lower Jurassic) part of the Hierlatz Limestone Formation in Hierlatz Alpe, Hallstatt, Austria.

Genus Laevitomaria Conti et Szabó, 1987

Type species - Pyrgotrochus? problematicus Szabó, 1980

Laevitomaria periferialis (Szabó, 1980)

(Figs 134-136)

1980 Pyrgotrochus periferialis sp. n. - SzABó, p. 62, pl. 3, fig. 6.

1987 Laevitomaria periferialis Szabó - Conti \& SzABó, p. 46.

2009 Laevitomaria periferialis Szabó - SzABó, p. 48, fig. 41.

Material - Two fragmentary specimens (GBA 2018/002/0011/01-02), representing the early teleoconch.

Measurements - Diameter $15 \mathrm{~mm}$ (the figured one, GBA 2018/002/0011/01), $13 \mathrm{~mm}$ (GBA 2018/002/0011/02).

Description - The specimens have rather high conoidal shells of quite high whorls with feebly convex surface and slightly impressed suture. A prominently wide selenizone runs slightly below the midwhorl, its width is about $20 \%$ of the suture to suture distance.

On a small surface of a whorl, the ornament is well preserved; it consists predominantly of spiral threads, which are crossed by weak riblets above and below the suture. The subsutural ones diminish in short distance in abapical direction but the elements of the other row terminate at the rim of the selenizone. The selenizone has a median spiral thread and sparse, weak lunulae on the earliest visible whorl; the lunulae are lacking subsequently.

Remarks - Both specimens well correspond to the type material from the Bakony Mts. These are the first finds of Laevitomaria periferialis in the Hierlatz Alpe fauna; that is why they are remarkable.

Distribution - In the Bakony Mts, this species occurs in beds with mixed Obtusum to Ibex Zone fauna and in the Davoei Zone (Late Sinemurian to Early Pliensbachian). This interval and that of the deposition of the Hierlatz Limestone in the type locality area are partly contemporaneous. 


\section{Laevitomaria sp.}

(Figs 137-139)

Material - A single fragmentary, early teleoconch (GBA 2018/002/0012).

Measurements - Height: $11.5 \mathrm{~mm}$, width: $11.5 \mathrm{~mm}$.

Description - Four early teleoconch whorls with slightly convex surface and feebly impressed suture represent this species. The shell has a wide selenizone in midwhorl position. Just above the suture, a swollen belt in its early form is visible; this is a frequent morphological element in Laevitomaria. The peripheral angulation of the latest whorl indicates a rather flat base.

Network ornament of sharp spiral and collabral threads covers the whorls both above and below the selenizone that bears sparse lunulae and a midwhorl thread in similar strength and density as the neighbouring belts.

Remarks - The form and the network ornament refer to an early teleoconch of an unidentifiable Laevitomaria species.
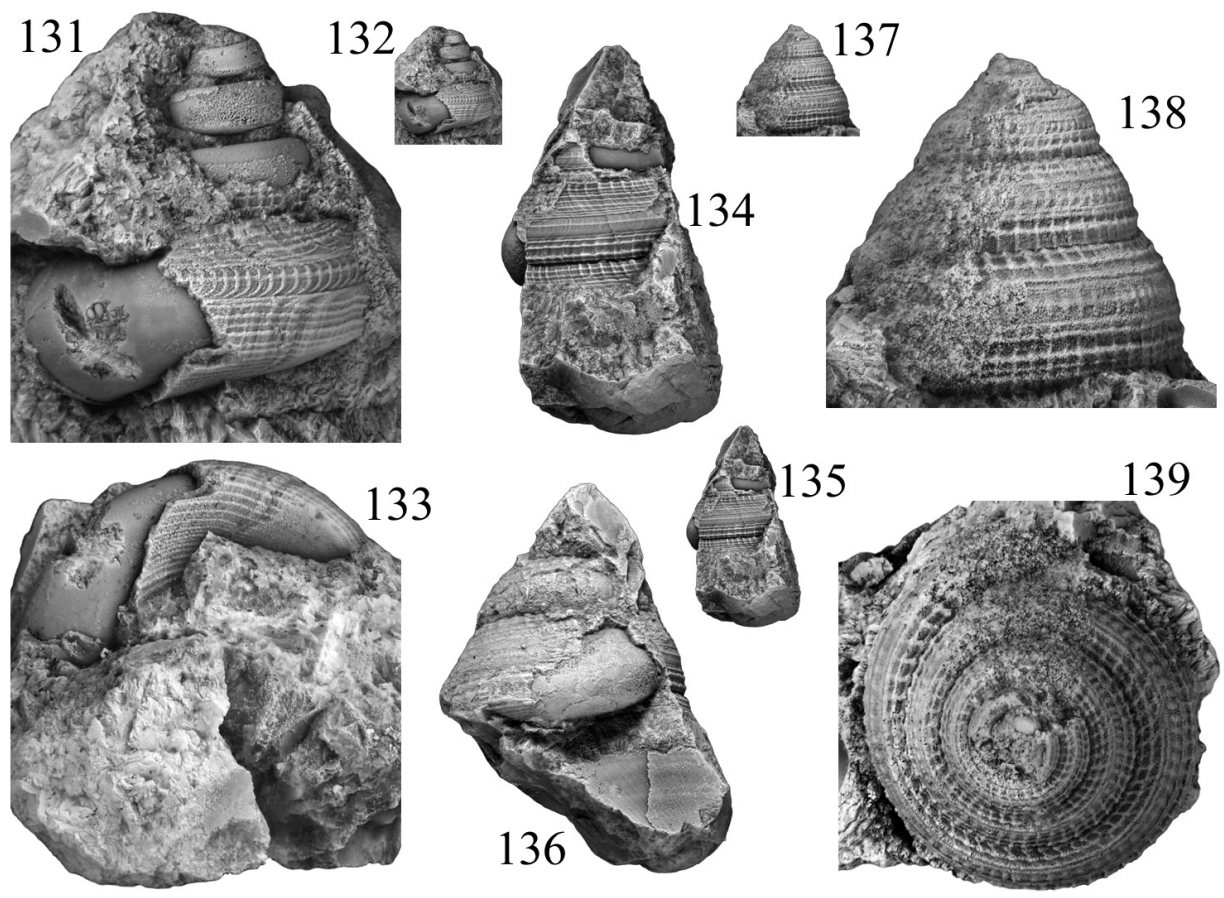

Figs 131-139. Laevitomaria species. - 131-133. Laevitomaria? sp. (GBA 2018/002/0013). - 131132. Lateral view $(\times 3.6$ and $\times 1)$. -133 . Basal view $(\times 3.6)$. - 134-136. Laevitomaria periferialis (Szabó, 1980) (GBA 2018/002/0011/01). - 134-135. Lateral view $(\times 2$ and $\times 1)$. - 136. Apertural view (×2). - 137-139. Laevitomaria sp. (GBA 2018/002/0012). - 137-138. Lateral view $(\times 1$ and $\times 3)$. 139. Apical view $(\times 3)$ 
Distribution - Within Sinemurian to lowermost Pliensbachian (Lower Jurassic) part of the Hierlatz Limestone Formation in Hierlatz Alpe, Hallstatt, Austria.

Laevitomaria? sp.

(Figs 131-133)

Material - A single specimen (GBA 2018/002/0013), consisting of four whorls of an early teleoconch.

Measurements - Diameter: $11 \mathrm{~mm}$.

Description - A conoidal shell, which has convex and rather high whorls without angulation on the surface between the sutures, and with a wide midwhorl selenizone. A rounded angulation is the transition from the whorl surface to the base, which is slightly convex with convex wall; there is no information about its axial region.

The ornament consists of two kinds of network of equally strong collabral and spiral threads on the last two whorls of the specimen; the adapical whorl has an early network that is more regularly built than that of the subsequent whorl. The ornament of the selenizone is composed of a thin thread slightly above the midline and sparse, asymmetric lunulae. Only spiral threads ornament the base.

Remarks - This shell has higher and more convex whorls than the other two Laevitomaria species of this paper. Since the last whorl is comparable to some Bathrotomaria species just before development of the angulation of the whorl surface, the genus identification is questionable.

Distribution - Within Sinemurian to lowermost Pliensbachian (Lower Jurassic) part of the Hierlatz Limestone Formation in Hierlatz Alpe, Hallstatt, Austria.

\section{? Family Pleurotomariidae Swainson, 1840 \\ Genus Granulizona n. gen.}

Type species - Granulizona mandli n. sp.

Diagnosis - Trochiform shell with blunt apex and low, slightly convex whorls without spiral angulation on whorl surface; latest whorls more convex than early ones. Selenizone with median cord below midwhorl; base flattened subconoidal with slightly convex wall; rather broadly phaneromphalous. Last whorl turning into base through angular periphery. Early teleoconch bearing collabral riblets above selenizone and tubercles below. Cord of selenizone ornamented by granules. During growth, riblets and tubercles along sutures gradually vanishing but density of granules on selenizone increasing then fusing into smooth cord. Spiral threads of various thickness present on all whorls and on base.

Derivation of name - Referring to the granulate selenizone of the early teleoconch. 
Description - See type species below.

Remarks - Since the earliest shell, the protoconch and one or two whorls, is insufficiently known, the family attribution is uncertain.

Some elements of the morphology and the ornament recall those of Pleurotomaria, Laevitomaria or Pyrgotrochus; see details of the comparison in the "Remarks" of the type species below.

Species - Granulizona mandli n. sp.

Distribution - Within Sinemurian to lowermost Pliensbachian (Lower Jurassic) part of the Hierlatz Limestone Formation in Hierlatz Alpe, Hallstatt, Austria.

\section{Granulizona mandli n. sp.}

(Figs 140-145)

Type specimen - Holotype: GBA 2018/002/0015.

Type locality - Hierlatz Alpe (Hallstatt, Austria).

Type strata - Hierlatz Limestone within the Lower Sinemurian to lowermost Pliensbachian (Lower Jurassic) interval.

Derivation of name - This species is dedicated to Gerhard Mandl, Austrian geologist (GBA).

Diagnosis - Same as for Granulizona n. gen., see above.

Material - A single, rather poorly preserved specimen that shows yet sufficient details to taxonomical treatment; the protoconch and the latest, near-peristome parts are unknown.

Measurements - Height: $33.5 \mathrm{~mm}$, width: $31.5 \mathrm{~mm}$.

Description - A moderately turriculate, trochiform shell of about 12-13 rather low whorls represents this species. The protoconch and about one of the earliest teleoconch whorls are very poorly preserved, the next eight visible whorls have feebly acute (coeloconoidal) outline but the last three whorls turn into slightly cyrtoconoidal. The suture is impressed along the full visible length of the shell. The earliest two visible whorls are flattened and have a shallow depression along the selenizone that seems flat here. In the next growth phases, the whorls gradually change into fully flat first then increasingly convex. Concomitantly the selenizone becomes convex from the third visible whorl, and rises higher than the arch of the whorls, like a weak carina. From the initial midwhorl position, the selenizone gradually shifts quite near to the lower suture during the growth. Its width is about $10 \%$ of the distance between the neighbouring two sutures. Below a narrow outer face, the shell turns through a slightly rounded angulation into the base that is rather flattened cone as a whole; its wall is feebly convex. Remnants of at least a half additional but broken whorl indicate presence of a 
rather wide phaneromphalus. No part of the peristome has been preserved but the growth-lines indicate a strongly prosocline outer lip with a slight sinus in an extremely abapical position, near the rim of the base.

Short, regularly repeating riblets ornament the belt adapically from the selenizone on the first five visible teleoconch whorls. Synchronously with the riblets, nodules develop along the abapical suture and tiny granules appear also on the selenizone; their periodicity is similar to those of the riblets and nodules but they are formed in different phase. The riblets and nodules gradually vanish on the fifth visible whorl while the granules of the selenizone remain present also on

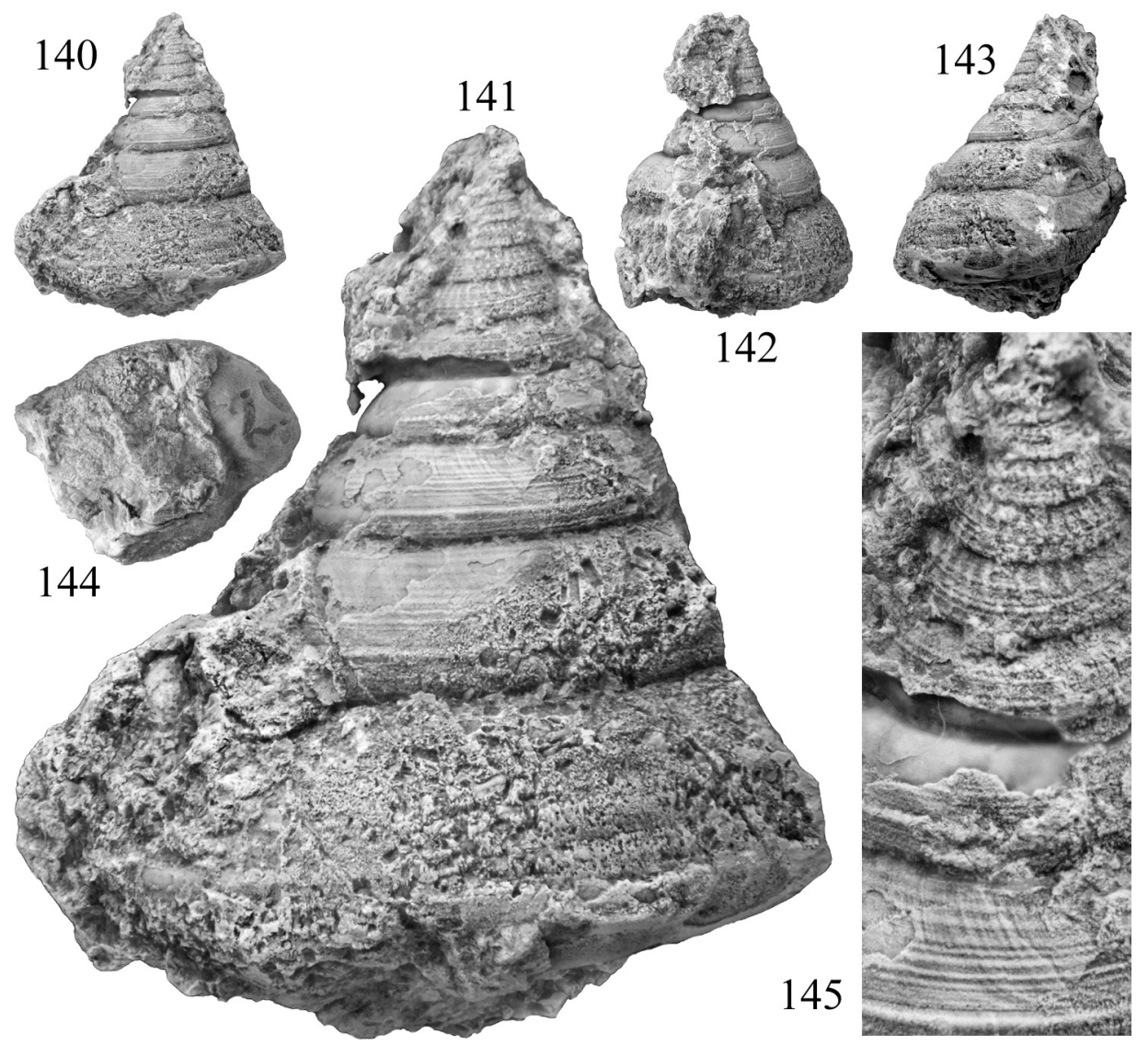

Figs 140-145. Granulizona mandli n. sp., holotype (GBA 2018/002/0015). - 140-141. Lateral view with the best preserved spots of the ornament $(\times 1$ and $\times 2.8)$. $142-143$. Lateral views, which clearly show the trochiform outline $(\times 1)$. - 144. Basal view $(\times 1)$. -145 . Details of the ornament and the alteration of the sculpture between the early and latest whorls $(\times 6)$ 
the next two whorls, devoid of riblets, but their density gradually increases then they fuse into a continuous keel, persisting along the following whorls. Variably strong growth-lines, which irregularly become strengthened as threads sometimes, mean the transverse ornament on the remaining parts of the shell. They are strongly prosocline and prosocyrt adapically from the selenizone and feebly opisthocline-prosocyrt in the narrow belt abapically. The growth-lines of the selenizone are invisible, probably they are extremely fine and erosion and/or the recrystallisation has smoothed them. Subregularly spaced spiral lines and threads are present on the whole outer surface of the shell excepting the selenizone and perhaps some belts of the base.

Remarks - The shape and ornament of the latest whorls resemble to those of Laevitomaria Conti et Szabó, 1987 species but the early whorls with sparse riblets between the upper suture and the selenizone, and granulae on the selenizone distinguish these two genera. The same early whorls in Granulizona n. gen. remind Pleurotomaria Defrance, 1826 but the lack of an angulation from the whorls and mainly the presence of the granulae on the selenizone are distinctive characters. Since the position of the selenizone is near the abapical suture on the last whorls, a distinction from Pyrgotrochus Fischer, 1885 is also necessary. Differently from Pyrgotrochus, these whorls are clearly convex and the outline of the shell is trochiform in Granulizona but the shell shape is coeloconoidal or conoidal in Pyrgotrochus with mostly flat or concave whorls and, in addition, a peripheral swollen belt somehow develops.

Distribution - Within Sinemurian to lowermost Pliensbachian (Lower Jurassic) part of the Hierlatz Limestone Formation in Hierlatz Alpe, Hallstatt, Austria.

\section{CONCLUSION}

The above pages introduce a dozen of more or less atypical Pleurotomaria or probably allied species. Most of them show some differences from the characteristic Pleurotomaria shape; the gradate outline has developed rudimentarily or it is missing to various extent. Sometimes "mixed" morphology appears or only the ornament indicates some relation to the typical Pleurotomaria, i.e. to the morphotype, represented by $P$. anglica. This phenomenon is observable also in other Tethyan gastropod faunas, e.g. in the Saltrio (Southern Alps, Italy) Sinemurian (Parona 1893, Sacchi Vialli 1964).

Subordinately, typical Pleurotomaria species also occur, in the Hierlatz Alpe fauna under the species name "aff. anglica"; in lack of satisfactory data about the variability of this species, a reliable revision of the Tethyan specimens has 
yet been impossible; $P$. deshayesii J. A. Eudes-Deslongchamps, 1849 is actually also an atypical species with its ramp-less latest whorls. Some other species (see SzABó 2009), connected to the Pleurotomaria name by open nomenclature, represent also extreme forms and some may belong to different genera, like one of the specimens from Pyrgotrochus? cf. precatoria, which is designated here as holotype of Neorotomaria obertraunensis n. sp.

Pleurotomaria suessi Hörnes, 1853, P. debuchii J. A. Eudes-Deslongchamps, 1849 and $P$.? laponya n. sp. and the similarly shaped species can hardly be kept within the frames of genus Pleurotomaria as it has already been expressed by Monari \& GatTo (2013).

The high number of the seemingly endemic Pleurotomaria (-like) species indicate a diversification of this genus, environmentally and/or geographically isolated from the European epicontinental seas. This process might begin in pre-Sinemurian times as part of the Early Jurassic recovery period after the Late Triassic mass extinction, contemporaneously with the tectonic disintegration of the former carbonate platforms, providing wide scale of horizontally and vertically diversified habitats to speciation.

Acknowledgements - I am grateful to Stefano Monari (Padua, Italy) and Boglárka Erdei (Budapest, Hungary) for their careful review and improvements of the manuscript.

\section{REFERENCES}

Conti M. A. \& Szabó J. 1987: Comparison of Bajocian gastropod faunas from the Bakony Mts. (Hungary) and Umbria (Italy). - Annales historico-naturales Musei nationalis hungarici 79: 43-59.

CLARK W. B. 1887: Ueber den geologischen Verhältnisse der Gegend nordwestlich vom Aachensee mit Besonderer Berücksichtigung der Bivalven und Gastropoden des unteren Lias. - Inaugural Dissertation Universität München, 45 pp.

HAUER F. voN 1853: Über die Gliederung der Trias-, Lias- und Juragebilde in den nordöstlichen Alpen. - Jahrbuch der kaiserlich-königlichen Geologischen Reichsanstalt 4: 715-784.

Monari S. \& Gatto R. 2013: Pleurotomaria Defrance, 1826 (Gastropoda, Mollusca) from the Lower Bajocian (Middle Jurassic) sediments of Luxembourg, with considerations on its systematics, evolution and palaeobiogeographical history. - Palaeontology 56(4): 751-781. http://dx.doi.org/10.1111/pala.12014

Monari S., VAlentini M. \& Conti M. A. 2011: Earliest Jurassic patellogastropod, vetigastropod, and neritimorph gastropods from Luxembourg with considerations on the TriassicJurassic faunal turnover. - Acta Palaeontologica Polonica 56(2): 349-384. http://dx.doi.org/10.4202/app.2010.0098

PARona C. F. 1893: I gasteropodi del Lias inferiore di Saltrio in Lombardia. - Bollettino della Società Malacologica Italiana 18: 161-184. 
SACCHI Vialli G. 1964: Revisione della fauna di Saltrio. V: I Gasteropodi. I Cefalopodi Dibranchiati. I Briozoi. I Brachiopodi. Gli Echinodermi. I Vertebrati - Atti dell'stituto di Geologia dell'Universitá di Pavia 15: 3-11.

StoliczKa F. 1861: Über die Gastropoden und Acephalen der Hierlatz-Schichten. - Sitzungsberichte der matematisch-naturwissenschaftliche Classe der kaiserlich-königlichen Akademie der Wissenschaften 43: 157-204, pls. 1-7.

Szabó J. 1980: Lower and Middle Jurassic Gastropods from the Bakony Mountains (Hungary). Part II. Pleurotomariacea and Fissurellacea (Archaeogastropoda). - Annales historico-naturales Musei nationalis hungarici 72: 49-71.

Szabó J. 2008: A nomenclatorial revision of Pleurotomaria suessii Hörnes, 1853 and Cyclostomaria Szabó, 1980 (Pleurotomarioidea, Gastropoda). - Neues Jahrbuch für Mineralogie und Paläontologie Abhadlungen 250(2): 167-176. http://dx.doi.org/10.1127/0077-7749/2008/0250-0167

SzABó J. 2009: Gastropods of the Early Jurassic Hierlatz Limestone Formation; part 1: a revision of type collections from Austrian and Hungarian localities. - Fragmenta Palaeontologica Hungarica 26: 1-108.

SzABó J. 2017: Gastropods of the Lower Jurassic Hierlatz Limestone Formation, part 2. Some new archaic type slit-bearing components from the fauna of the Hierlatz Alpe (Hallstatt, Austria) and the Bakony Mts (Hungary). - Fragmenta Palaeontologica Hungarica 33: 3-30.

http://dx.doi.org/10.17111/FragmPalHung.2016.33.3 